\title{
Blood-Brain Barrier Pathology and CNS Outcomes in Streptococcus pneumoniae Meningitis
}

\author{
Belinda Yau ${ }^{1, *}$, Nicholas H. Hunt ${ }^{1}$, Andrew J. Mitchell ${ }^{2}$ and Lay Khoon Too ${ }^{1}$ \\ 1 Molecular Immunopathology Unit, Bosch Institute and School of Medical Sciences, University of Sydney, \\ Sydney 2006, Australia; nicholas.hunt@sydney.edu.au (N.H.H.); laykhoon.too@sydney.edu.au (L.K.T.) \\ 2 Materials Characterisation and Fabrication Platform, Department of Chemical Engineering, University of \\ Melbourne, Melbourne 3010, Australia; andrew.mitchell1@unimelb.edu.au \\ * Correspondence: belinda.yau@sydney.edu.au; Tel.: +61-(0)415-838-782
}

Received: 19 October 2018; Accepted: 9 November 2018; Published: 11 November 2018

\begin{abstract}
Streptococcus pneumoniae is a major meningitis-causing pathogen globally, bringing about significant morbidity and mortality, as well as long-term neurological sequelae in almost half of the survivors. Subsequent to nasopharyngeal colonisation and systemic invasion, translocation across the blood-brain barrier (BBB) by S. pneumoniae is a crucial early step in the pathogenesis of meningitis. The BBB, which normally protects the central nervous system (CNS) from deleterious molecules within the circulation, becomes dysfunctional in S. pneumoniae invasion due to the effects of pneumococcal toxins and a heightened host inflammatory environment of cytokines, chemokines and reactive oxygen species intracranially. The bacteria-host interplay within the CNS likely determines not only the degree of BBB pathological changes, but also host survival and the extent of neurological damage. This review explores the relationship between $S$. pneumoniae bacteria and the host inflammatory response, with an emphasis on the BBB and its roles in CNS protection, as well as both the acute and long-term pathogenesis of meningitis.
\end{abstract}

Keywords: Streptococcus; pneumonia; pneumococcal; meningitis; blood-brain barrier; infection; inflammation

\section{Introduction}

Bacterial meningitis is an inflammatory disease of the central nervous system (CNS), diagnosed by the presence of bacteria within the cerebrospinal fluid (CSF). Gram-positive Streptococcus pneumoniae is a primary cause of meningitis in the developing world [1], alongside other pathogens such as Haemophilus influenzae [2] and Neisseria meningitides [1,3]. Pneumococcus-mediated blood-brain barrier (BBB) breakdown causes acute symptoms that range from fever, headache and neck stiffness, to severe CNS complications including hydrocephalus, brain oedema, intracranial haemorrhage, cerebral venous and arterial complications and seizures that contribute to mortality and long-term disabilities [4]. Mortality rates in human patients are between 20\% and 50\% [5-7], with long-term neurological outcomes such as hearing loss, aphasia, learning impairments and chronic seizures observed in up to $60 \%$ of patients after bacterial clearance [8-11].

Despite continuing advances in vaccines and adjuvant therapies, bacterial meningitis is a persistent health problem because of obstacles that include increasing antibiotic resistance [12,13], serotype replacement [14-16] and vaccine failure [17]. Significantly, while research on how S. pneumoniae interacts with the brain environment is rapidly evolving, our understanding of the pathogenesis of BBB disruption in pneumococcal meningitis (PM) at the molecular level remains incomplete. This review focuses on S. pneumoniae-derived factors that drive CNS invasion via the BBB 
and addresses the implications of BBB pathology in CNS complications in the acute disease state, as well as neurological sequelae post-recovery.

\section{The BBB in Acute PM}

\subsection{Structure and Function of the $B B B$}

The BBB is a critical structure protecting against invasion of the CNS by pathogens. It consists of specialist endothelial cells that express highly selective tight junctions, and regulatory and supporting pericytes and astrocytic foot processes along a basal membrane (reviewed in [18]). Additional supporting cells include perivascular macrophages (PVM), resident myeloid cells located within the perivascular space that localise adjacent to cerebral blood vessels and regulate vascular stability [19]. PVM are suggested to be key candidates for communication between the CNS and the periphery [20]. Within the brain, astrocytes support BBB function, mediating endothelial and neuron interactions [21], while microglia can mount an antigen-independent innate immune response by pivoting the balance between anti- and pro-inflammatory macrophages [22]. As a functional barrier of continuous non-fenestrated cells between the circulation and brain interstitial fluid, the BBB serves not only to regulate the passage of ions and molecules, ensuring CNS homeostasis and protection from toxins and pathogenic invaders [23], but also to regulate host immune cell extravasation into the brain parenchyma and thus influence local inflammatory responses [24].

By shielding the CNS from peripheral immune cells and antibodies, the BBB has contributed to what has been classically defined as CNS immune privilege, though our understanding of CNS immune surveillance is still evolving [25-27]. Newly discovered lymphatic vessels in the dura mater, the meningeal lymphatic system, have been demonstrated to drain both fluid and immune cells from the subarachnoid space into deep cervical lymph nodes, and may indicate significant roles for these vessels in lymphocyte trafficking and antigen presentation [28]. The presence of CNS lymphatics enables non-pathological movement of leukocytes, such as memory T-lymphocytes, into the CNS, and this is thought to be essential for normal neurological function [29]. T-cell status may also be switched by BBB endothelial cells that act as semi-professional antigen-presenting cells (APC) [30]. As both a physical and immunological barrier, the BBB therefore acts as a key determinant of protective homeostatic surveillance during brain infections [31].

\subsection{Pneumococcal Transmigration across the BBB into the CNS}

The key bacterial factors affecting S. pneumoniae bloodstream-to-CNS invasion across the BBB are summarised in Table 1 and illustrated in Figure 1.

Colonisation of the intranasal cavity by S. pneumoniae is the first step to PM pathogenesis. The bacterium is inhaled through airborne droplets and colonises the mucosal surfaces of the nasopharynx. Asymptomatic nasal carriage of S. pneumoniae occurs in almost $30 \%$ of all individuals [32-34], with higher rates observed in children and neonates [35]. Transmission between humans in close contact means that communities often share $S$. pneumoniae serotype profiles, and this may account for variations in population susceptibility to invasive disease [35,36]. From the nasopharynx, S. pneumoniae can progress to the inner ear cavities, the lungs or invade the intravascular space within tissue to access the bloodstream-causing otitis media, pneumonia, or sepsis, respectively [37]. Once S. pneumoniae becomes blood-borne, meningitis is preceded by invasion of the CNS through the BBB or blood-CSF barrier [38], though olfactory neuron invasion also has been observed [39].

We now will discuss key virulence factors that lend advantages to $S$. pneumoniae in blood-to-brain parenchyma invasion, some of which are common to other meningitis-causing pathogens [40]: the pneumococcal capsule, bacterial surface proteins, and secreted proteins such as pneumolysin. 


\subsubsection{The Pneumococcal Capsule}

The pneumococcal capsule, a 200-400 nm thick polysaccharide wall that encompasses the exterior cell wall of S. pneumoniae, is a vital regulator of the bacterium's invasive capacity. Clinical isolates of S. pneumoniae are almost always encapsulated [41], with evidence that systemic dissemination in particular is dependent on maximum capsule expression [42]. High capsule expression enhances immune evasion; encapsulated S. pneumoniae display reduced neutrophil extracellular trap adhesion [43], and are more resistant to phagocytosis [44], capable of reducing complement deposition on their surface [45]. However, encapsulation is detrimental to successful colonisation [46], inhibiting binding sites of pneumococcal surface proteins (Psp) adhesion molecules on the S. pneumoniae cell wall that are required for epithelial cell binding and transcytosis. Unsurprisingly, successful S. pneumoniae variants are most capable of altering capsule expression through quorum sensing and phase regulation, transitioning the capsule from thick to transparent variations $[47,48]$ by modulating biosynthesis of oligosaccharide repeats on the cytoplasmic membrane, encoded at the capsular polysaccharide biosynthesis locus [42]. Evidence from serotype studies suggests that mechanisms of immune evasion (such as phagocytosis resistance) that are mediated through capsule regulation vary across serotypes.

\subsubsection{Pneumococcal Proteins}

Psp drive successful translocation at both nasopharyngeal/bloodstream and bloodstream/brain boundaries. S. pneumoniae pili enable bacterial attachment to endothelial cells [49] through pneumococcal pilus-1 [50]. Pilus-related adhesin (RrgA) binds both host Poly Immunoglobin Receptor (plgR) and platelet endothelial cell adhesion molecule (PECAM-1) to facilitate S. pneumoniae translocation across the BBB [51]. Surface neuraminidase A (NanA) can facilitate endothelial binding through the endothelial laminin G-like lectin domain [52]. There is evidence that initial translocation of S. pneumoniae at the BBB occurs with adhesion at the vascular endothelium of the subarachnoid vessels, before progression to endothelial cells of the cortex and choroid plexus [38].

Psp are important for bacterial entry into the CNS. Types of Psp known as choline-binding proteins (Cbp) attach to the cell surface of $S$. pneumoniae via phosphorylcholine and teichoic components of the pneumococcal cell wall [36]. Cbp include pneumococcal surface protein A (PspA) and choline-binding protein $\mathrm{A}(\mathrm{CbpA})$, which disrupt complement pathways to inhibit phagocytosis by immune cells [53-55]. Additionally, PspA increases S. pneumoniae resistance to killing by human apo-lactoferrin [56], which works in concert with lysozyme to induce pneumococcal lysis [57]. CbpA also binds to human immunoglobin receptors [58,59], including PlgR [60], as well as platelet-activating factor (PAF) receptors on endothelial cells [38]. As such, CbpA can mediate mucosal invasion, as well as S. pneumoniae transport across the BBB [60] through the pneumococcal-PAF complex [38,61]. Downregulated CbpA expression is associated with impaired S. pneumoniae colonisation [62]. Furthermore, pneumococcal phospholipase A2 (PLA2), which is a secreted bacterial enzyme that also modulates inflammation [63], is a clinical predictor for PM [64]. PLA2 production is associated with upregulation of adhesion molecules in host vascular endothelial cells [65].

Cell wall components and S. pneumoniae-derived enzymes also contribute to virulence. Peptidoglycan and teichoic acid have long been known to activate toll-like receptor (TLR)-mediated inflammation [66], while NanA can alter the viscosity of the mucous environment, cleaving $\mathrm{N}$-acetylneuraminic acid from mucin, glycoproteins, glycolipids and oligosaccharides [67], and exposing host epithelial cells to S. pneumoniae contact. Pneumococcal IgA1 protease cleaves protective host secretory IgA [68], hyaluronidase degrades connective tissue extracellular matrix component hyaluronan [69], contributing to increased virulence [70], and hydrogen peroxide production mediated by the pyruvate oxidase (SpxB) gene offers competitive advantage in microbial competition [71]. 


\subsubsection{Pneumolysin}

The 53-kDa pore-forming toxin pneumolysin (ply) is a major virulence factor produced by S. pneumoniae. Present within the bacterial cytoplasm, it is overrepresented in clinically isolated strains [72] and may either be released during autolysis or actively exported from the cell wall [73]. As its name suggests, pneumolysin is cytolytic. It binds host cell membranes and triggers formation of a pre-pore, puncturing the cell membrane and initiating conformational changes within the host cell to create a mature ply pore [74]. The resulting presence of the mature ply pore in host cells drives protein influx and imbalances in signal transduction [75]. Pneumolysin is also a stimulator of classical complement pathways [75], and of both TLR and the nucleotide-binding oligomerisation domain (Nod)-like receptor (NLR)-activated inflammasome pathways [76,77]. It also activates NADPH oxidase and induces reactive oxygen species production in neutrophils in a manner dependent on pneumococcal autolysin LytA [78].

Ply is also likely to play critical roles not only in the processes of bacterial translocation across the BBB, but also in neuropathology. Ply interferes with brain ependymal cilia $[79,80]$, has direct cytotoxic effects on both epithelial and endothelial cells [81], and triggers microglial and neuronal cell death [82,83]. Ply-induced pore formation also affects glial cells, altering astrocytic cell structure and increasing overall BBB permeability [84]. Clinically, extended ply presence in the CSF correlates with mortality in PM [85]. In experimental PM, mice infected with ply-deficient serotype 2 bacteria were protected from invasive disease [86]. However, we have found that infection with serotype 3 and 4 strains deficient in ply leads to reduced TLR-mediated inflammation at the expense of increased bacterial load [87].

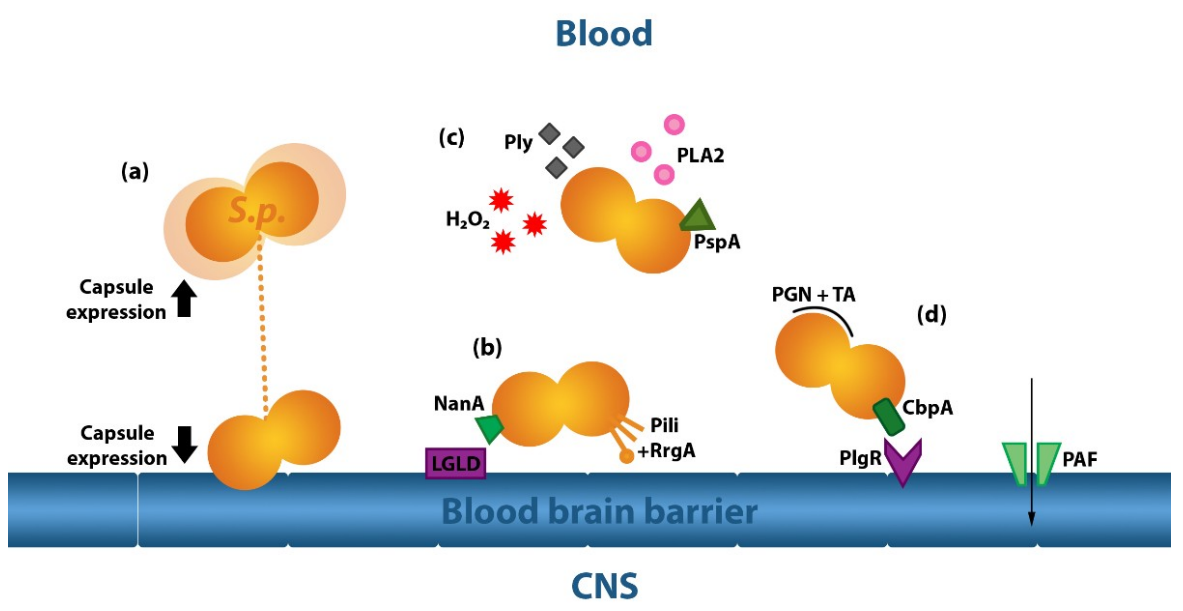

Figure 1. S. pneumoniae-mediated CNS invasion and BBB transmigration in PM. (a) S. pneumoniae regulates high capsule expression, which promotes immune cell evasion, and low capsule expression, which promotes endothelial cell adhesion. Dark arrows represent direction of capsule expression; (b) NanA can bind endothelial LGLD, while pili and adhesin RgrA further increase bacterial attachment to endothelial cells, facilitating their BBB translocation; (c) secreted proteins include PLA2, which upregulates endothelial adhesins, and hydrogen peroxide and ply, which regulate the overall BBB environment by activating pro-inflammatory host processes leading to cytokine induction and RONS production, as well as directly damaging host endothelial cells; (d) PspA interferes with host killing and opsonophagocytosis of S. pneumoniae by immune cells, while bacterial cell wall components PGN and TA activate host inflammatory responses through TLR activation. CbpA also inactivates complement pathways, binds human immunoglobin receptor PlgR, and facilitates S. pneumoniae translocation across the BBB through the endothelial PAF receptors. Light arrow represents route of S. pneumoniae transport. BBB-blood-brain barrier, $\mathrm{CbpA}$-choline binding protein A, CNS — central nervous system, $\mathrm{H}_{2} \mathrm{O}_{2}$ - hydrogen peroxide, LGLD—laminin G-like lectin domain, NanA—neuraminidase A, PAF-platelet-activating factor, PGN-peptidoglycan, PLA2-pneumococcal phospholipase A2, PlgR-poly immunoglobin receptor, ply-pneumolysin, PspA-pneumococcal surface protein A, RONS — reactive oxygen and nitrogen species, RgrA—pilus-related adhesin, TA—teichoic acid. 
Table 1. S. pneumoniae-derived virulence factors and their modes of action in contributing to CNS invasion, and BBB transmigration and dysfunction in PM.

\begin{tabular}{|c|c|c|c|}
\hline & Virulence Factor & Mode(s) of Action & Reference(s) \\
\hline \multirow{2}{*}{ Capsule } & $\begin{array}{l}\text { Thick polysaccharide } \\
\text { capsule }\end{array}$ & $\begin{array}{l}\text { Reduce neutrophil extracellular trapping } \\
\text { Reduce phagocytosis } \\
\text { Reduce complement deposition }\end{array}$ & $\begin{array}{l}{[43]} \\
{[44]} \\
{[45]}\end{array}$ \\
\hline & $\begin{array}{l}\text { Thin polysaccharide } \\
\text { capsule }\end{array}$ & $\begin{array}{l}\text { Expose pneumococcal surface protein binding } \\
\text { sites }\end{array}$ & {$[43-45]$} \\
\hline \multirow[b]{2}{*}{ Pili } & Pneumococcal pilus-1 & Increase attachment to endothelial cells & [51] \\
\hline & Pilus adhesin RrgA & $\begin{array}{l}\text { Facilitates BBB translocation through } \mathrm{pIgR} \text { and } \\
\text { PECAM-1 binding }\end{array}$ & [51] \\
\hline \multirow[b]{2}{*}{ Choline binding proteins } & $\begin{array}{l}\text { Pneumococcal surface } \\
\text { protein A (PspA) }\end{array}$ & $\begin{array}{l}\text { Interferes with complement factor B } \\
\text { Inhibits human apo-lactoferrin activity }\end{array}$ & {$[53]$} \\
\hline & $\begin{array}{l}\text { Choline-binding protein } \\
\mathrm{A}(\mathrm{CbpA})\end{array}$ & $\begin{array}{l}\text { Inactivates } \mathrm{C} 3 \mathrm{~b} \text { through complementary factor } \\
\mathrm{H} \text { binding } \\
\text { Facilitates } \mathrm{BBB} \text { translocation through plgR and } \\
\text { PAF receptors on endothelial cells }\end{array}$ & $\begin{array}{c}{[54,55]} \\
{[38,51,60]}\end{array}$ \\
\hline \multirow[b]{2}{*}{ Cell wall } & Peptidoglycan & Activates host TLR, increasing inflammation & [66] \\
\hline & Teichoic Acid & $\begin{array}{l}\text { Binds choline-binding proteins to } \\
\text { pneumococcal cell wall } \\
\text { Activates host TLR, increasing inflammation }\end{array}$ & $\begin{array}{l}{[36]} \\
{[66]}\end{array}$ \\
\hline Pneumococcal surface proteins & Neuraminidase A & $\begin{array}{l}\text { Cleaves N-acetylneuraminic acid } \\
\text { Facilitates endothelial binding through LGLD }\end{array}$ & {$[67]$} \\
\hline \multirow{5}{*}{ Secreted } & $\begin{array}{l}\text { Pneumococcal IgA } \\
\text { protease }\end{array}$ & Cleaves host secretory IgA & [68] \\
\hline & Hyaluronidase & Degrades hyaluronan & [69] \\
\hline & $\begin{array}{l}\text { Pneumococcal } \\
\text { phospholipase A2 } \\
\text { (PLA2) }\end{array}$ & $\begin{array}{l}\text { Increases inflammation } \\
\text { Associated with upregulation of endothelial } \\
\text { cell adhesins }\end{array}$ & $\begin{array}{l}{[63]} \\
{[65]}\end{array}$ \\
\hline & Hydrogen peroxide & Kills competing microbes & [71] \\
\hline & Pneumolysin & $\begin{array}{l}\text { Cytolytic through ply pore formation to } \\
\text { epithelial, endothelial and glial cells } \\
\text { Stimulates complement pathways } \\
\text { Activates TLR and NLR inflammasome } \\
\text { pathways } \\
\text { Activates NADPH oxidase } \\
\text { Activates ROS production in neutrophils } \\
\text { Disrupts ependymal cilia }\end{array}$ & $\begin{array}{c}{[74,81-84]} \\
{[75]} \\
{[76,77]} \\
{[78]} \\
{[78]} \\
{[79,80]}\end{array}$ \\
\hline
\end{tabular}

\subsection{Role of the Host Inflammatory Response in Determining Outcome in PM}

The immune mediators in PM involved in BBB dysfunction that are discussed in this section are summarised in Table 2, and illustrated in Figure 2.

\subsubsection{Microglia and Immune Activation}

As the resident macrophages of the brain, microglia are early defence immune system regulators [88,89]. They phagocytose live S. pneumoniae [90,91] and are capable of sensing pathogen-associated molecular patterns (PAMPs) through pattern recognition receptors (PRRs) such as TLR and NLR. In response to bacterial invasion, microglia release cytokines and chemokines to instigate a leukocyte infiltration response to bacterial invasion, present antigen to T-cells [92], and may have direct cytotoxic effects on S. pneumoniae through antimicrobial peptides [93]. 


\subsubsection{Pattern Recognition Receptors}

A range of PRR pathways are triggered within the CNS during pneumococcal meningitis and these influence outcome not only through the host anti-bacterial response but also the associated disruption of CNS function. TLRs are present on glial cells (reviewed in [94]) and have selective capacities to sense a diverse range of PAMPs and danger-associated molecular patterns (DAMPs) of bacterial origin. In PM, a number of virulence factors or pneumococcal proteins can trigger these receptors [95]. For instance, surface-bound TLR2 on glial cells is activated upon recognition of peptidoglycan and lipoteichoic acid in the S. pneumoniae cell wall [96-98], while ply stimulates TLR4 [76,99]. Endosomal TLR9 responds to S. pneumoniae CpG motifs in genomic DNA [100], but requires prior surface recognition and uptake of S. pneumoniae into endolysosomes or phagolysosomes [101]. In addition to TLRs, NLRs localise within the cytosol, alongside pyrin and hematopoietic interferon-inducible nuclear antigens with a 200-amino-acid repeat (HIN) domain-containing proteins (PYHIN), to sense intracellular PAMPs and DAMPs (reviewed in [102]). A subfamily of NLRs containing an N-terminal pyrin domain can form multi-protein structures termed inflammasomes, a number of which are sensors of S. pneumoniae PAMPs [103]. The inflammasomes consist of the PRR, an adapter protein (typically), and the enzyme caspase-1 (CASP1). In PM, the NLR family pyrin domain containing 3 (NLRP3) inflammasome is activated by ply [104] through extracellular ATP [105]-induced lysosomal disruption and Cathepsin B release [106]. Similarly, the PYHIN protein Absent in Melanoma 2 (AIM2) inflammasome complex responds to cytosolic pneumococcal DNA release from phagolysosomes, which may in turn be dependent upon ply-induced lysis [103,107]. Inflammasome activation ultimately results in CASP1 cleavage of pro-forms of interleukin-1-beta (IL-1 $\beta$ ) and interleukin-18 (IL-18) into active releasable forms [108]. Release of active IL-1 $\beta$ contributes to increased inflammation [109], while IL-18 release modulates interferon-gamma (IFN $\gamma$ )-dependent pathogenesis in PM [110].

\subsubsection{Leukocyte Infiltration and the Cytokine Storm}

Following PRR-mediated microglial activation, glia-initiated leukocyte infiltration drives the proinflammatory response associated with PM. Local production of interleukin-6 (IL-6), tumour necrosis factor (TNF) and IL-1 $\beta$ from endothelial cells, microglia and astrocytes occurs prior to leukocyte infiltration, with heightened levels of these cytokines characteristic of both clinical [111-114] and experimental $[110,115-118]$ PM. It is likely that PVM also have supportive roles in leukocyte transmigration, with PVM depletion being associated with reduced leukocytosis into the subarachnoid space in PM [119].

Upregulation of chemokines in the CNS is characteristic of PM, and these are involved in both leukocyte recruitment and migration. Produced by resident immune cells including microglia, the chemokines chemokine (C-C motif) ligand (CCL)2, CCL3, chemokine (C-X-C motif) ligand(CXCL) 8 and CXCL1 regulate neutrophil, monocyte and T-cell chemotaxis, while CXCL1 and CXCL3 are associated with Natural Killer cell recruitment [120]. At the BBB, integrin activation by chemokines such as CXCL12, CCL11 and CCL21 induces leukocyte adhesion [121], with CXCL12 demonstrated to induce both arrest and crawling of $\mathrm{T}$ cells, as well as mediate adhesion of monocytes on human vascular endothelial cells in vitro [122]. Mechanisms behind leukocyte diapedesis in the CNS are not well defined, though transmigration of leukocytes occurs either through the paracellular route between endothelial cells or the transcellular route through BBB cells [123], with granulocyte transmigration showing preference for transcellular routes [124].

Neutrophils likely have multifaceted roles in controlling S. pneumoniae in the brain. In PM, neutrophils comprise $90 \%$ of infiltrating leukocytes [118], and though high white blood cell counts are associated with improved clinical outcomes [125], experimental leukocyte depletion reduces CNS injury and increases survival rates [126]. In contrast, specific neutrophil depletion leads to increased bacterial numbers in the brain and worsened survival in mice [127], and prolonged neutrophil presence in the CNS increases haemorrhage and oedema [128]. In the long term, after PM has been cured by antibiotic treatment, neutrophil-depleted mice display improved behavioural and learning outcomes 
compared to their non-depleted counterparts [129]. Elucidating the dual protective and harmful roles of leukocytes in CNS infection is crucial to understanding pathogenesis and developing therapies for PM [130].

The presence of leukocytes within the CNS further contributes to the cytokine environment established by resident CNS cells, creating a "cytokine storm". CSF levels of the archetypal inflammatory cytokines TNF, IL- $1 \beta$, IFN $\gamma$ and IL-6 are consistently measurable in clinical PM [116,131,132] and correlate with meningitis mortality [133]. In experimental PM, high intrathecal levels of TNF correspond with increased neutrophil infiltration and BBB breakdown [134], though complete TNF deficiency results in increased mortality [135]. IL-6 gene knockout mice similarly display increased mortality [136], though in this case BBB permeability and brain oedema are diminished [137]. Reduced levels of IL-1 $\beta$ in CASP1 gene knockout mice are associated with improved BBB integrity [138]; however, IL-1 receptor knockout mice were found to have greater BBB invasion, with increased numbers of pneumococci in the CNS [139], indicating that aspects of IL-1 signalling are involved in host protection in PM. IFN $\gamma$ levels, in particular, correlate with PM in bacterial meningitis caused by other agents [114,135], with increased CSF levels reported in both human patients $[114,140]$ and experimental models $[110,118,141,142]$. IFN $\gamma$ activates macrophages and antigen-presenting cells and, along with IL-1 $\beta$, regulates production of other cytokines [143], making it a critical regulator of the cytokine storm. It is produced by resident CNS cells, infiltrating Natural Killer cells and activated T cells [144] and in PM its production is induced via a pathway involving an inflammasome, IL-12 and IL-18 [110,144]. IFN $\gamma$ gene knockout mice are protected from mortality in experimental PM and display improved bacterial clearance in the CSF and reduced BBB permeability [110]. Together, these studies highlight the seeming inconsistency and complexity of the cytokine environment in the regulation of BBB integrity and PM pathogenesis.

\subsubsection{Reactive Oxygen and Nitrogen Species}

Reactive oxygen and nitrogen species (RONS) are released by resident CNS cells, such as microglia and endothelial cells, as well as infiltrating leukocytes during phagocytosis [145], and their levels are elevated in patient CSF and both the CSF and brains of experimental animals with PM [146]. Endothelial NADPH oxidase is protective against BBB disruption in PM [147]. However, RONS also drive multiple aspects of host CNS damage, including BBB breakdown [148]. Upon entry into the CNS, S. pneumoniae continues to multiply or undergo autolysis, with either process capable of inducing hydrogen peroxide production, causing cytotoxicity to nearby host cells [149]. Hydrogen peroxide also reacts with host-derived nitric oxide to form peroxynitrite, which in turn is capable of host cell membrane disruption through lipid peroxidation [145], protein carbonyl formation and activation of matrix metalloproteinases [150]. Additionally, hydrogen peroxide conversion to hypochlorous acid by neutrophil-derived myeloperoxidase activates matrix metalloproteinase (MMP)-9, driving BBB breakdown [151]. In PM, treatment with peroxynitrite scavengers alongside antibiotic therapy leads to decreased local IL-1 $\beta$ levels and reduced leukocyte infiltration into the CSF [145]. Similarly, treatment with the hydrogen peroxide scavenger catalase, and superoxide dismutase, reduces brain oedema in PM $[152,153]$.

Nitrite/nitrate and nitric oxide metabolites are observed in the brains of meningitis patients and experimental animals [154], while nitric oxide synthases (NOS) such as NOS2 are specifically linked to BBB breakdown and augmented proinflammatory cytokine profiles in experimental PM [132,155], as well as regulating caspase-3-driven neuronal apoptosis in the hippocampus [156]. Interestingly, endothelial NOS (NOS1) appears to have a protective role, with NOS1 deficiencies associated with increased BBB breakdown, leukocyte infiltration [133] and mortality [157]. In contrast, inducible NOS (NOS2) is produced by infiltrating monocytes and regulated in part by IFN $\gamma$ in experimental PM [132]. Increased NOS2 expression correlates with increased serum nitrite levels, BBB permeability and protein influx into the brain, with NOS2 deficiency associated with complete BBB protection, alongside reduced oedema, lower concentrations of proinflammatory cytokines in the brain, and 
lessened mortality [132]. Correspondingly, free radical scavenger treatment that reduced NOS2 levels in the PM brain also correlated with decreased leukocyte infiltration and improved mortality [158].

Overall, RONS play both protective and deleterious roles, and the sites of production and action of these molecules likely determine their impact in PM.

\subsubsection{Matrix Metalloproteinases}

Matrix metalloproteinases (MMPs), which are zinc-dependent endopeptidases, are secreted by activated leukocytes [159] and are implicated specifically in BBB damage in PM. MMPs degrade the extracellular matrix [160] and MMP8 and MMP9 are measurably increased in the CSF of patients with bacterial meningitis [161], with MMP9 associated with BBB dysfunction and neuronal apoptosis $[133,162]$. MMP inhibition in conjunction with antibiotic treatment protects from experimental hippocampal injury in PM [162,163] and improves survival [164], with MMP2 and MMP9 single and dual-inhibition reducing BBB breakdown in the hippocampus and/or the cortex [165]. Correspondingly, the metalloproteinase tumour necrosis factor alpha converting enzyme (TACE) is implicated in augmenting MMP release [166], with TACE inhibition being protective against CNS damage, neurological symptoms and mortality in experimental PM [163].

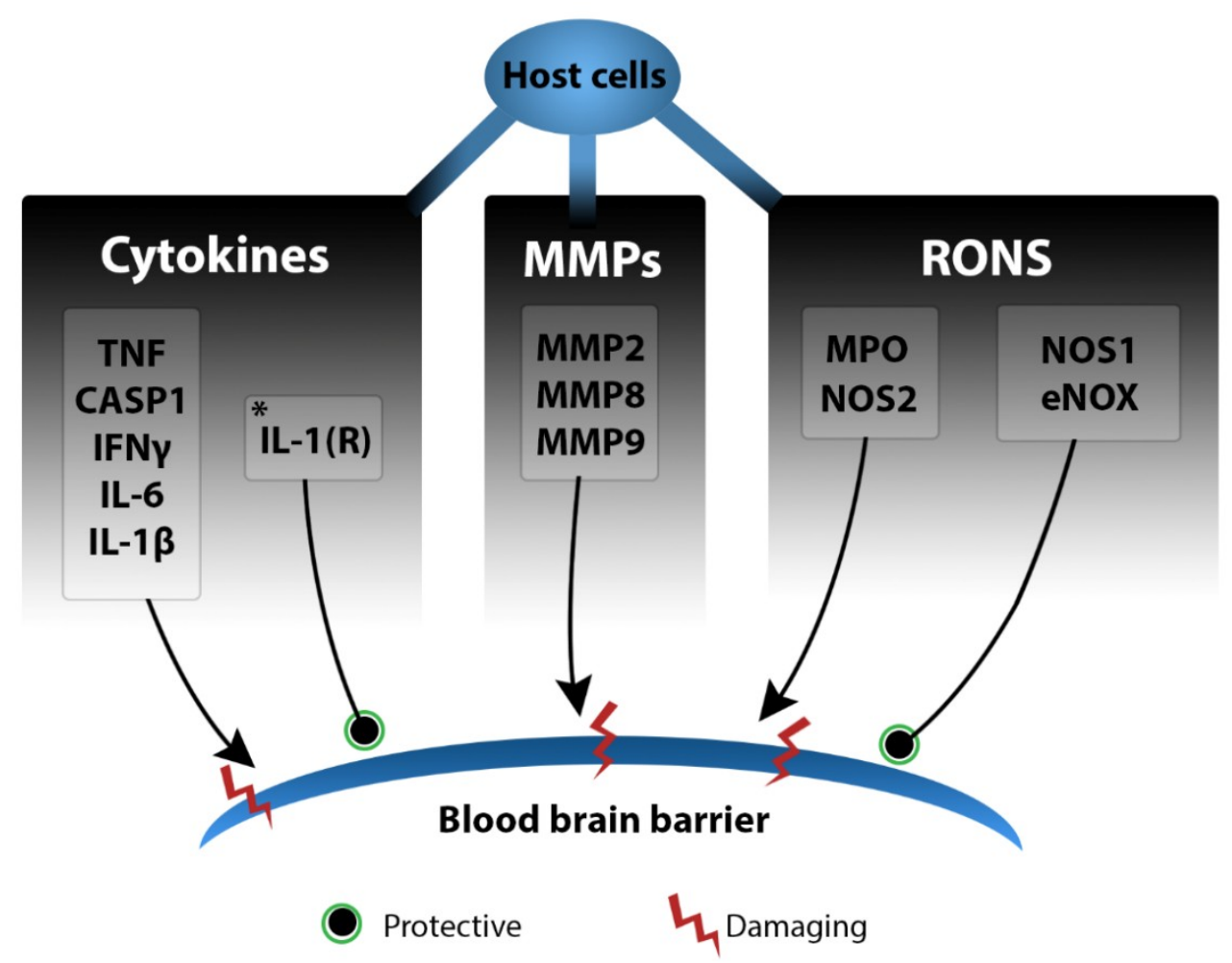

Figure 2. Host-derived components involved in BBB dysfunction. Resident immune cells and infiltrating leukocytes contribute to the cytokine storm, producing proinflammatory mediators TNF, CASP1, IFN $\gamma$, IL-1 $\beta$ and IL-6 associated with increase BBB breakdown. However, some aspects of IL-1 signalling through IL-1R may be partially BBB protective. MMP2, 8 and 9 contribute to BBB dysfunction, alongside neutrophil-derived MPO and monocyte-derived NOS2. Endothelial-derived NOS1 is protective of BBB integrity, as is endothelial NADPH oxidase. Arrows to red lines indicate damage, arrows to green circles indicate protection. CASP1—caspase-1, eNOX — endothelial NADPH (nicotinamide adenine dinucleotide phosphate) oxidase, IFN $\gamma$-interferon-gamma, IL-1 $\beta$-interleukin-1-beta, IL-1(R-interleukin-1(receptor), IL-6-interleukin-6, MMP — matrix metalloproteinase, MPO-myeloperoxidase, NOS-nitric oxide synthase, RONS - reactive oxygen and nitrogen species, TNF-tumour necrosis factor. 
Table 2. Host-derived mediators associated with immune modulation and BBB permeability.

\begin{tabular}{|c|c|c|c|}
\hline & Mediator & Associated Immune Consequence in PM & Reference(s) \\
\hline \multirow{3}{*}{ Chemokines } & $\begin{array}{l}\text { CCL2 } \\
\text { CCL3 } \\
\text { CXCL8 }\end{array}$ & Monocyte, neutrophil and T-cell recruitment & \multirow[t]{2}{*}{ [120] } \\
\hline & $\begin{array}{l}\text { CXCL1 } \\
\text { CXCL3 }\end{array}$ & $\begin{array}{c}\text { Monocyte, neutrophil and T-cell recruitmentNatural } \\
\text { Killer cell recruitment } \\
\text { Natural Killer cell recruitment }\end{array}$ & \\
\hline & $\begin{array}{l}\text { CXCL12 } \\
\text { CCL11 } \\
\text { CCL21 }\end{array}$ & $\begin{array}{l}\text { Activates endothelial cell integrins to induce } \\
\text { leukocyte adhesion }\end{array}$ & {$[121,122]$} \\
\hline \multirow{6}{*}{ Cytokines } & TNF & $\begin{array}{c}\text { Induces neutrophil infiltrationIncreased BBB } \\
\text { breakdown }\end{array}$ & [134] \\
\hline & IL-1 $\beta$ & Regulates inflammatory cytokines & [143] \\
\hline & IL-6 & Increased BBB permeability & [137] \\
\hline & IFN- $\gamma$ & $\begin{array}{l}\text { Activates macrophages and T-cellsRegulates } \\
\text { inflammatory cytokinesIncreases BBB permeability }\end{array}$ & {$[110,143,144]$} \\
\hline & CASP1 & Regulates IL-1 $\beta$ & [138] \\
\hline & CASP3 & Increases hippocampal apoptosis & [156] \\
\hline \multirow{4}{*}{ RONS } & $\mathrm{H}_{2} \mathrm{O}_{2}$ & $\begin{array}{l}\text { Increases neuronal damage } \\
\text { Increases lipid peroxidation } \\
\text { Increases and activates MMPs } \\
\text { Increases brain oedema }\end{array}$ & $\begin{array}{c}{[149]} \\
{[145]} \\
{[150]} \\
{[152,153]}\end{array}$ \\
\hline & eNOX & Protects against BBB damage & [147] \\
\hline & NOS1 & $\begin{array}{l}\text { Reduces leukocyte infiltration into the CNSProtects } \\
\text { against BBB damage }\end{array}$ & [133] \\
\hline & NOS2 & $\begin{array}{l}\text { Increases serum nitriteIncreases leukocyte } \\
\text { infiltration into the CNSIncreases BBB permeability }\end{array}$ & {$[132,158]$} \\
\hline \multirow{2}{*}{ MMPs } & MMP2 & Increases BBB permeability & [167] \\
\hline & MMP9 & $\begin{array}{c}\text { Increases BBB permeabilityIncreases neuronal } \\
\text { apoptosis }\end{array}$ & {$[133,162,165]$} \\
\hline
\end{tabular}

\section{BBB Disruption and Long-Term Neurological Sequelae in PM}

As reviewed above, evasion of host physical and immune barriers allows pneumococci to enter the CNS, which triggers a cascade of inflammatory responses and the recruitment of immune cells to the site. This process leads to a permeable BBB that allows both S. pneumoniae and infiltrating leukocytes to further augment the host immune response via multiple positive feedback loops. A well-balanced host immune reaction facilitates complete recovery from PM. However, dysregulated immune responses might occur in many PM cases, which contributes to wide-ranging neurological complications that result in life-long disabilities, including behavioural disorders, cognitive impairments and hearing deficits [167].

In general, dysregulated host inflammatory responses result in two primary catastrophic events-oxidative stress and cytokine storm. These two events are linked to cellular injury and damage, including disrupting the BBB to further trigger long-lasting brain damage. Treatment with antioxidants has beneficial effects against long-term neurological deficiencies in experimental PM. Peroxynitrite scavengers reduce hearing loss [168], while adjuvant treatment with N-acetylcysteine reduces both memory loss and hearing loss $[168,169]$. In a similar vein, adjuvant administration of matrix metalloproteinase inhibitors in experimental PM reduces damage to BBB and cortex and restores cognitive impairment $[164,165]$, while neuronal damage in the hippocampus has been found to be correlated positively with learning disabilities and cognitive deficits in both human and animal meningitis survivors [170]. 
The cytokine storm, and its clinical implications for the CNS, have been reviewed recently [171]. Notable pro- and anti-inflammatory mediators involved in driving the pathogenesis of PM, such as IL-6, IL-1 $\beta$, IFN- $\gamma$, IL-10 and transforming growth factor-beta (TGF- $\beta$ ), have been shown to modulate neural progenitor cells' survival, proliferation and differentiation [172]. Excessive expression of IL-6, TNF and IL-1 $\beta$ - the major cytokines contributing to sickness behaviours during acute PM - may lead to long-lasting sensitisation of neural or endocrine circuits, such as the hypothalamus-pituitary-adrenal (HPA), that modulate emotion, behaviour and cognition [173-175]. In experimental PM, acute IL-1 $\beta$ levels correlate with the incidence of neurological sequelae [176], and inversely associate with BBB integrity [138].

Exposure to pathological levels of inflammatory cytokines may also lead to irreversible cellular genetic changes via epigenetic mechanisms, thereby contributing to altered neuro-behavioural functions [177]. In our study [141], we found reduced BBB permeability and cytokine production in mice deficient in IFN- $\gamma$ compared to their WT counterparts. In the long term, IFN $\gamma$ gene knockout mice with suppressed immune reactions were shown to survive PM with decreased hippocampal and cortical brain damage, which was linked to improved behavioural disorders and cognitive flexibility. Unlike other gene knockout mouse strains (TLR2/4, IFN $\gamma$ and NOS2) observed in our study, about $60 \%$ of Myeloid differentiation primary response 88 (MyD88) gene knockout mice, which have a substantially attenuated inflammatory response, including reduced leukocytosis and pro-inflammatory cytokine and chemokine production during acute PM, retained their hearing ability as measured by Preyer's reflex [178].

Altogether, these findings implicate oxidative factors and several cytokines in causing the long-term neurological impacts of PM in survivors of acute disease.

\section{Concluding Remarks}

BBB repair as therapy is currently underutilised. Glucocorticosteroid treatment in multiple sclerosis has been shown to improve BBB integrity and downregulate BBB-compromising effectors such as VEGF [179]. In patients, adjuvant corticosteroid treatment reduced mortality alongside hearing loss and neurological sequelae in adults with PM [180], and dexamethasone used as adjunctive therapy alongside antibiotics reduces CSF levels of MMP9—a previously implicated regulator of BBB damage—as well as overall CNS inflammation and long-term deficits [165,181].

Preserving BBB integrity is key to neurological protection in infectious brain diseases such as bacterial meningitis, as well as non-infectious neurological diseases, including Alzheimer's disease, epilepsy, ischemic stroke and multiple sclerosis. It is well recognised that the induction of cytokines, oxidative stress, as well as the production of bacterial toxins, compromise BBB integrity in PM, and this is subsequently associated with causing both acute intracranial complications and lasting neurological dysfunction. Figure 3 provides an overview of the known players that drive BBB damage. Our current review of the implications of BBB pathology in PM pathogenesis identifies a shortfall in the field. The measurement of BBB disruption is uncommon in meningitis studies, and CNS leukocytosis and/or heightened pro-inflammatory cytokines and chemokines are generally an accepted proxy for BBB breakdown. The findings reviewed herein hopefully provide insight into BBB maintenance as a potential therapeutic target and the importance of addressing the BBB in the understanding of PM pathogenesis. 


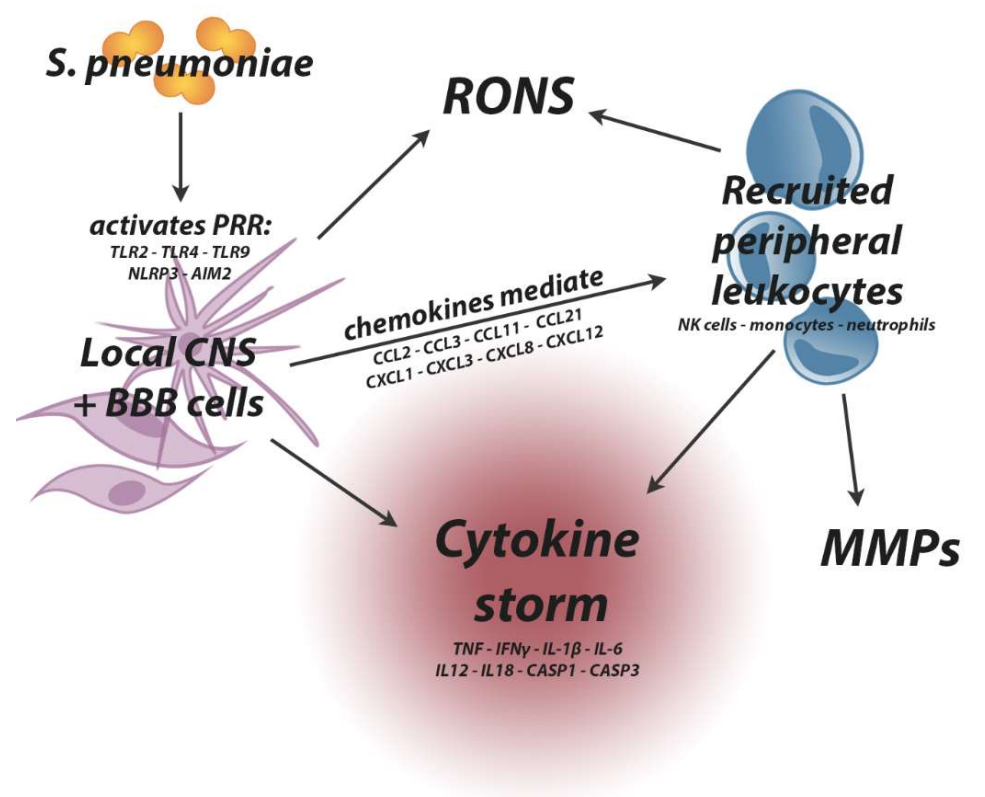

Figure 3. Interactions between S. pneumoniae, the brain and the peripheral immune system drives pathogenesis in PM. S. pneumoniae activates resident CNS and BBB cells through PRR to initiate the inflammatory response. Chemokines released in the brain mediate recruitment and infiltration of peripheral leukocytes, including neutrophils, monocytes, macrophages and Natural Killer cells, into the brain. Local glial and endothelial cells and recruited immune cells produce RONS and cytokines, while leukocytes also produce MMPs. Black arrows indicate direction of interaction. BBB-blood-brain barrier, CNS - central nervous system, MMPs—-matrix metalloproteinases, PRR—pattern recognition receptors, RONS—reactive oxygen and nitrogen species.

Author Contributions: B.Y. contributed to study design, research, writing, data interpretation, manuscript revision. N.H.H. contributed to writing, data interpretation, manuscript revision. A.J.M. contributed to data interpretation, manuscript revision. L.K.T. contributed to study design, writing, data interpretation, manuscript revision.

Funding: The authors' studies reported here were supported by the National Health and Medical Research Council of Australia (Project grant 571024). B.Y. was supported by an Australian Postgraduate Research Award. L.K.T. was sponsored by a scholarship provided by the Ministry of Science, Technology and Innovation (MOSTI) of Malaysia.

Conflicts of Interest: The authors declare no conflict of interest.

\section{Abbreviations}

APC

ASC

BBB

CASP1

$\mathrm{Cbp}$

CNS

CSF

DAMP
Antigen-presenting cells apoptosis-associated speck-like protein containing a CARD domain blood-brain barrier

caspase-1

choline-binding proteins

central nervous system

cerebrospinal fluid

danger-associated molecular patterns 


$\begin{array}{ll}\text { HPA } & \text { hypothalamus-pituitary-adrenal } \\ \text { IFN } \gamma & \text { interferon-gamma } \\ \text { IL-1 } \beta & \text { interleukin-1-beta } \\ \text { IL-6 } & \text { interleukin-6 } \\ \text { IL-12 } & \text { interleukin-12 } \\ \text { IL-18 } & \text { interleukin-18 } \\ \text { LytA } & \text { pneumococcal autolysin } \\ \text { MMP } & \text { matrix metalloproteinase } \\ \text { MyD88 } & \text { myeloid differentiation primary response 88 } \\ \text { NanA } & \text { neuraminidase A } \\ \text { NLR } & \text { Nod-like receptor } \\ \text { NLRP3 } & \text { Nod-like receptor (NLR) family pyrin domain containing 3 } \\ \text { NOS } & \text { nitric oxide synthase } \\ \text { PAF } & \text { platelet-activating factor } \\ \text { PAMP } & \text { pathogen-associated molecular patterns } \\ \text { PECAM-1 } & \text { platelet endothelial cell adhesion molecule } \\ \text { PLA2 } & \text { pneumococcal phospholipase } 2 \\ \text { plgR } & \text { poly immunoglobin receptor } \\ \text { ply } & \text { pneumolysin } \\ \text { PM } & \text { pneumococcal meningitis } \\ \text { PRR } & \text { pattern recognition receptors } \\ \text { Psp } & \text { pneumococcal surface proteins } \\ \text { PspA } & \text { pneumococcal surface protein A } \\ \text { PVM } & \text { perivascular macrophages } \\ \text { RONS } & \text { reactive oxygen and nitrogen species } \\ \text { ROS } & \text { reactive oxygen species } \\ \text { TACE } & \text { tumour necrosis factor alpha converting enzyme } \\ \text { TGF- } \beta & \text { transforming growth factor-beta } \\ \text { TLR } & \text { tumour necrosis factor } \\ \text { TNF } & \end{array}$

\section{References}

1. Scarborough, M.; Thwaites, G.E. The diagnosis and management of acute bacterial meningitis in resource-poor settings. Lancet Neurol. 2008, 7, 637-648. [CrossRef]

2. Watt, J.P.; Wolfson, L.J.; O’Brien, K.L.; Henkle, E.; Deloria-Knoll, M.; McCall, N.; Lee, E.; Levine, O.S.; Hajjeh, R.; Mulholland, K.; et al. Burden of disease caused by Haemophilus influenzae type b in children younger than 5 years: Global estimates. Lancet 2009, 374, 903-911. [CrossRef]

3. Scarborough, M.; Gordon, S.B.; Whitty, C.J.; French, N.; Njalale, Y.; Chitani, A.; Peto, T.E.; Lalloo, D.G.; Zijlstra, E.E. Corticosteroids for bacterial meningitis in adults in sub-Saharan Africa. N. Engl. J. Med. 2007, 357, 2441-2450. [CrossRef] [PubMed]

4. Mook-Kanamori, B.B.; Geldhoff, M.; van der Poll, T.; van de Beek, D. Pathogenesis and pathophysiology of pneumococcal meningitis. Clin. Microbiol. Rev. 2011, 24, 557-591. [CrossRef] [PubMed]

5. Schuchat, A.; Robinson, K.; Wenger, J.D.; Harrison, L.H.; Farley, M.; Reingold, A.L.; Lefkowitz, L.; Perkins, B.A. Bacterial meningitis in the United States in 1995. Active Surveillance Team. N. Engl. J. Med. 1997, 337, 970-976. [CrossRef] [PubMed]

6. Gessner, B.D.; Mueller, J.E.; Yaro, S. African meningitis belt pneumococcal disease epidemiology indicates a need for an effective serotype 1 containing vaccine, including for older children and adults. BMC Infect. Dis. 2010, 10, 22. [CrossRef] [PubMed]

7. Goetghebuer, T.; West, T.E.; Wermenbol, V.; Cadbury, A.L.; Milligan, P.; Lloyd-Evans, N.; Adegbola, R.A.; Mulholland, E.K.; Greenwood, B.M.; Weber, M.W. Outcome of meningitis caused by Streptococcus pneumoniae and Haemophilus influenzae type $\mathrm{b}$ in children in The Gambia. Trop. Med. Int. Health 2000, 5, 207-213. [CrossRef] [PubMed] 
8. Goldberg, D.W.; Tenforde, M.W.; Mitchell, H.K.; Jarvis, J.N. Neurological sequelae of adult meningitis in Africa: A systematic literature review. Open Forum Infect. Dis. 2018, 5, ofx246. [CrossRef] [PubMed]

9. Ramakrishnan, M.; Ulland, A.J.; Steinhardt, L.C.; Moïsi, J.C.; Were, F.; Levine, O.S. Sequelae due to bacterial meningitis among African children: A systematic literature review. BMC Med. 2009, 7, 47. [CrossRef] [PubMed]

10. Christie, D.; Viner, R.M.; Knox, K.; Coen, P.G.; Wang, H.; El Bashir, H.; Legood, R.; Patel, B.C.; Booy, R. Long-term outcomes of pneumococcal meningitis in childhood and adolescence. Eur. J. Pediatr. 2011, 170, 997-1006. [CrossRef] [PubMed]

11. Legood, R.; Coen, P.G.; Knox, K.; Viner, R.M.; El Bashir, H.; Christie, D.; Patel, B.C.; Booy, R. Health related quality of life in survivors of pneumococcal meningitis. Acta Paediatr. 2009, 98, 543-547. [CrossRef] [PubMed]

12. Whitney, C.G.; Farley, M.M.; Hadler, J.; Harrison, L.H.; Lexau, C.; Reingold, A.; Lefkowitz, L.; Cieslak, P.R.; Cetron, M.; Zell, E.R.; et al. Increasing prevalence of multidrug-resistant Streptococcus pneumoniae in the United States. N. Engl. J. Med. 2000, 343, 1917-1924. [CrossRef] [PubMed]

13. Leach, A.J.; Morris, P.S.; McCallum, G.B.; Wilson, C.A.; Stubbs, L.; Beissbarth, J.; Jacups, S.; Hare, K.; Smith-Vaughan, H.C. Emerging pneumococcal carriage serotypes in a high-risk population receiving universal 7-valent pneumococcal conjugate vaccine and 23-valent polysaccharide vaccine since 2001. BMC Infect. Dis. 2009, 9, 121. [CrossRef] [PubMed]

14. Okade, H.; Funatsu, T.; Eto, M.; Furuya, Y.; Mizunaga, S.; Nomura, N.; Mitsuyama, J.; Yamagishi, Y.; Mikamo, H. Impact of the pneumococcal conjugate vaccine on serotype distribution and susceptibility trends of pediatric non-invasive Streptococcus pneumoniae isolates in Tokai, Japan over a 5-year period. J. Infect. Chemother. 2014, 20, 423-428. [CrossRef] [PubMed]

15. Pichon, B.; Ladhani, S.N.; Slack, M.P.; Segonds-Pichon, A.; Andrews, N.J.; Waight, P.A.; Miller, E.; George, R. Changes in molecular epidemiology of streptococcus pneumoniae causing meningitis following introduction of pneumococcal conjugate vaccination in England and Wales. J. Clin. Microbiol. 2013, 51, 820-827. [CrossRef] [PubMed]

16. Regev-Yochay, G.; Reisenberg, K.; Katzir, M.; Wiener-Well, Y.; Rahav, G.; Strahilevitz, J.; Istomin, V.; Tsyba, E.; Peretz, A.; Khakshoor, S.; et al. Pneumococcal Meningitis in Adults after Introduction of PCV7 and PCV13, Israel, July 2009-June 2015. Emerg. Infect. Dis. 2018, 24, 1275-1284. [CrossRef] [PubMed]

17. Antachopoulos, C.; Tsolia, M.N.; Tzanakaki, G.; Xirogianni, A.; Dedousi, O.; Markou, G.; Zografou, S.M.; Eliades, A.; Kirvassilis, F.; Kesanopoulos, K.; et al. Parapneumonic pleural effusions caused by Streptococcus pneumoniae serotype 3 in children immunised with 13-valent conjugated pneumococcal vaccine. Pediatr. Infect. Dis. J. 2014, 33, 81-83. [CrossRef] [PubMed]

18. Serlin, Y.; Shelef, I.; Knyazer, B.; Friedman, A. Anatomy and physiology of the blood-brain barrier. Semin. Cell Dev. Biol. 2015, 38, 2-6. [CrossRef] [PubMed]

19. He, H.; Mack, J.J.; Güç, E.; Warren, C.M.; Squadrito, M.L.; Kilarski, W.W.; Baer, C.; Freshman, R.D.; McDonald, A.I.; Ziyad, S.; et al. Perivascular macrophages limit permeability. Arterioscler. Thromb. Vasc. Biol. 2016, 36, 2203-2212. [CrossRef] [PubMed]

20. Herz, J.; Filiano, A.J.; Smith, A.; Yogev, N.; Kipnis, J. Myeloid Cells in the Central Nervous System. Immunity 2017, 46, 943-956. [CrossRef] [PubMed]

21. Sharif, Y.; Jumah, F.; Coplan, L.; Krosser, A.; Sharif, K.; Tubbs, R.S. The blood brain barrier: A review of its anatomy and physiology in health and disease. Clin. Anat. 2018. [CrossRef] [PubMed]

22. Van Sorge, N.M.; Doran, K.S. Defense at the border: The blood-brain barrier versus bacterial foreigners. Future Microbiol. 2012, 7, 383-394. [CrossRef] [PubMed]

23. Daneman, R.; Prat, A. The blood-brain barrier. Cold Spring Harb. Perspect. Biol. 2015, 7, a020412. [CrossRef] [PubMed]

24. Zhao, Z.; Nelson, A.R.; Betsholtz, C.; Zlokovic, B.V. Establishment and dysfunction of the blood-brain barrier. Cell 2015, 163, 1064-1078. [CrossRef] [PubMed]

25. Negi, N.; Das, B.K. CNS: Not an immunoprivilaged site anymore but a virtual secondary lymphoid organ. Int. Rev. Immunol. 2018, 37, 57-68. [CrossRef] [PubMed]

26. Louveau, A.; Harris, T.H.; Kipnis, J. Revisiting the mechanisms of CNS immune privilege. Trends Immunol. 2015, 36, 569-577. [CrossRef] [PubMed]

27. Engelhardt, B.; Vajkoczy, P.; Weller, R.O. The movers and shapers in immune privilege of the CNS. Nat. Immunol. 2017, 18, 123. [CrossRef] [PubMed] 
28. Aspelund, A.; Antila, S.; Proulx, S.T.; Karlsen, T.V.; Karaman, S.; Detmar, M.; Wiig, H.; Alitalo, K. A dural lymphatic vascular system that drains brain interstitial fluid and macromolecules. J. Exp. Med. 2015, 212, 991-999. [CrossRef] [PubMed]

29. Schwartz, M.; Kipnis, J. A conceptual revolution in the relationships between the brain and immunity. Brain Behav. Immun. 2011, 25, 817-819. [CrossRef] [PubMed]

30. Meyer, C.; Martin-Blondel, G.; Liblau, R.S. Endothelial cells and lymphatics at the interface between the immune and central nervous systems: Implications for multiple sclerosis. Curr. Opin. Neurol. 2017, 30, 222-230. [CrossRef] [PubMed]

31. Klein, R.S.; Hunter, C.A. Protective and pathological immunity during central nervous system infections. Immunity 2017, 46, 891-909. [CrossRef] [PubMed]

32. Pebody, R.G.; Morgan, O.; Choi, Y.; George, R.; Hussain, M.; Andrews, N. Use of antibiotics and risk factors for carriage of Streptococcus pneumoniae: A longitudinal household study in the United Kingdom. Epidemiol. Infect. 2009, 137, 555-561. [CrossRef] [PubMed]

33. Hammitt, L.L.; Bruden, D.L.; Butler, J.C.; Baggett, H.C.; Hurlburt, D.A.; Reasonover, A.; Hennessy, T.W. Indirect effect of conjugate vaccine on adult carriage of Streptococcus pneumoniae: An explanation of trends in invasive pneumococcal disease. J. Infect. Dis. 2006, 193, 1487-1494. [CrossRef] [PubMed]

34. Katsarolis, I.; Poulakou, G.; Analitis, A.; Matthaiopoulou, I.; Roilides, E.; Antachopoulos, C.; Kafetzis, D.A.; Daikos, G.L.; Vorou, R.; Koubaniou, C.; et al. Risk factors for nasopharyngeal carriage of drug-resistant Streptococcus pneumoniae: Data from a nation-wide surveillance study in Greece. BMC Infect. Dis. 2009, 9, 120. [CrossRef] [PubMed]

35. Ardanuy, C.; Tubau, F.; Pallares, R.; Calatayud, L.; Domínguez, M.A.; Rolo, D.; Grau, I.; Martín, R.; Liñares, J. Epidemiology of invasive pneumococcal disease among adult patients in Barcelona before and after pediatric 7-valent pneumococcal conjugate vaccine introduction, 1997-2007. Clin. Infect. Dis. 2009, 48, 57-64. [CrossRef] [PubMed]

36. Henriques-Normark, B.; Tuomanen, E.I. The pneumococcus: Epidemiology, microbiology, and pathogenesis. Cold Spring Harb. Perspect. Med. 2013, 3, a010215. [CrossRef] [PubMed]

37. Weiser, J.N.; Ferreira, D.M.; Paton, J.C. Streptococcus pneumoniae: Transmission, colonization and invasion. Nat. Rev. Microbiol. 2018, 16, 355-367. [CrossRef] [PubMed]

38. Iovino, F.; Orihuela, C.J.; Moorlag, H.E.; Molema, G.; Bijlsma, J.J. Interactions between blood-borne Streptococcus pneumoniae and the blood-brain barrier preceding meningitis. PLoS ONE 2013, 8, e68408. [CrossRef] [PubMed]

39. Van Ginkel, F.W.; McGhee, J.R.; Watt, J.M.; Campos-Torres, A.; Parish, L.A.; Briles, D.E. Pneumococcal carriage results in ganglioside-mediated olfactory tissue infection. Proc. Natl. Acad. Sci. USA 2003, 100, 14363-14367. [CrossRef] [PubMed]

40. Doran, K.S.; Fulde, M.; Gratz, N.; Kim, B.J.; Nau, R.; Prasadarao, N.; Schubert-Unkmeir, A.; Tuomanen, E.I.; Valentin-Weigand, P. Host-pathogen interactions in bacterial meningitis. Acta Neuropathol. 2016, 131, 185-209. [CrossRef] [PubMed]

41. Magee, A.D.; Yother, J. Requirement for capsule in colonization by Streptococcus pneumoniae. Infect. Immun. 2001, 69, 3755-3761. [CrossRef] [PubMed]

42. Kadioglu, A.; Weiser, J.N.; Paton, J.C.; Andrew, P.W. The role of Streptococcus pneumoniae virulence factors in host respiratory colonization and disease. Nat. Rev. Microbiol. 2008, 6, 288-301. [CrossRef] [PubMed]

43. Wartha, F.; Beiter, K.; Albiger, B.; Fernebro, J.; Zychlinsky, A.; Normark, S.; Henriques-Normark, B. Capsule and D-alanylated lipoteichoic acids protect Streptococcus pneumoniae against neutrophil extracellular traps. Cell. Microbiol. 2007, 9, 1162-1171. [CrossRef] [PubMed]

44. Middleton, D.R.; Paschall, A.V.; Duke, J.A.; Avci, F.Y. Enzymatic hydrolysis of pneumococcal capsular polysaccharide renders the bacterium vulnerable to host defense. Infect. Immun. 2018. [CrossRef] [PubMed]

45. Mitchell, A.M.; Mitchell, T.J. Streptococcus pneumoniae: Virulence factors and variation. Clin. Microbiol. Infect. 2010, 16, 411-418. [CrossRef] [PubMed]

46. Keller, L.E.; Jones, C.V.; Thornton, J.A.; Sanders, M.E.; Swiatlo, E.; Nahm, M.H.; Park, I.H.; McDaniel, L.S. PspK of Streptococcus pneumoniae increases adherence to epithelial cells and enhances nasopharyngeal colonization. Infect. Immun. 2013, 81, 173-181. [CrossRef] [PubMed] 
47. Li-Korotky, H.S.; Lo, C.Y.; Banks, J.M. Interaction of pneumococcal phase variation, host and pressure/gas composition: Virulence expression of NanA, HylA, PspA and CbpA in simulated otitis media. Microb. Pathog. 2010, 49, 204-210. [CrossRef] [PubMed]

48. Shainheit, M.G.; Mule, M.; Camilli, A. The core promoter of the capsule operon of Streptococcus pneumoniae is necessary for colonization and invasive disease. Infect. Immun. 2014, 82, 694-705. [CrossRef] [PubMed]

49. Bagnoli, F.; Moschioni, M.; Donati, C.; Dimitrovska, V.; Ferlenghi, I.; Facciotti, C.; Muzzi, A.; Giusti, F.; Emolo, C.; Sinisi, A.; et al. A second pilus type in Streptococcus pneumoniae is prevalent in emerging serotypes and mediates adhesion to host cells. J. Bacteriol. 2008, 190, 5480-5492. [CrossRef] [PubMed]

50. Iovino, F.; Hammarlöf, D.L.; Garriss, G.; Brovall, S.; Nannapaneni, P.; Henriques-Normark, B. Pneumococcal meningitis is promoted by single cocci expressing pilus adhesin RrgA. J. Clin. Investig. 2016, 126, 2821-2826. [CrossRef] [PubMed]

51. Iovino, F.; Engelen-Lee, J.Y.; Brouwer, M.; van de Beek, D.; van der Ende, A.; Valls Seron, M.; Mellroth, P.; Muschiol, S.; Bergstrand, J.; Widengren, J.; et al. pIgR and PECAM-1 bind to pneumococcal adhesins RrgA and PspC mediating bacterial brain invasion. J. Exp. Med. 2017, 214, 1619-1630. [CrossRef] [PubMed]

52. Uchiyama, S.; Carlin, A.F.; Khosravi, A.; Weiman, S.; Banerjee, A.; Quach, D.; Hightower, G.; Mitchell, T.J.; Doran, K.S.; Nizet, V. The surface-anchored NanA protein promotes pneumococcal brain endothelial cell invasion. J. Exp. Med. 2009, 206, 1845-1852. [CrossRef] [PubMed]

53. Neeleman, C.; Geelen, S.P.; Aerts, P.C.; Daha, M.R.; Mollnes, T.E.; Roord, J.J.; Posthuma, G.; van Dijk, H.; Fleer, A. Resistance to both complement activation and phagocytosis in type 3 pneumococci is mediated by the binding of complement regulatory protein factor H. Infect. Immun. 1999, 67, 4517-4524. [PubMed]

54. Smith, B.L.; Hostetter, M.K. C3 as substrate for adhesion of Streptococcus pneumoniae. J. Infect. Dis. 2000, 182, 497-508. [CrossRef] [PubMed]

55. Van der Maten, E.; Westra, D.; van Selm, S.; Langereis, J.D.; Bootsma, H.J.; van Opzeeland, F.J.; de Groot, R.; Ruseva, M.M.; Pickering, M.C.; van den Heuvel, L.P.; et al. Complement Factor H serum levels determine resistance to pneumococcal invasive disease. J. Infect. Dis. 2016, 213, 1820-1827. [CrossRef] [PubMed]

56. Mirza, S.; Benjamin, W.H., Jr.; Coan, P.A.; Hwang, S.A.; Winslett, A.K.; Yother, J.; Hollingshead, S.K.; Fujihashi, K.; Briles, D.E. The effects of differences in pspA alleles and capsular types on the resistance of Streptococcus pneumoniae to killing by apolactoferrin. Microb. Pathog. 2016, 99, 209-219. [CrossRef] [PubMed]

57. Andre, G.O.; Politano, W.R.; Mirza, S.; Converso, T.R.; Ferraz, L.F.; Leite, L.C.; Darrieux, M. Combined effects of lactoferrin and lysozyme on Streptococcus pneumoniae killing. Microb. Pathog. 2015, 89, 7-17. [CrossRef] [PubMed]

58. Dave, S.; Carmicle, S.; Hammerschmidt, S.; Pangburn, M.K.; McDaniel, L.S. Dual roles of PspC, a surface protein of Streptococcus pneumoniae, in binding human secretory IgA and factor H. J. Immunol. 2004, 173, 471-477. [CrossRef] [PubMed]

59. Hammerschmidt, S.; Tillig, M.P.; Wolff, S.; Vaerman, J.P.; Chhatwal, G.S. Species-specific binding of human secretory component to SpsA protein of Streptococcus pneumoniae via a hexapeptide motif. Mol. Microbiol. 2000, 36, 726-736. [CrossRef] [PubMed]

60. Orihuela, C.J.; Gao, G.; Francis, K.P.; Yu, J.; Tuomanen, E.I. Tissue-specific contributions of pneumococcal virulence factors to pathogenesis. J. Infect. Dis. 2004, 190, 1661-1669. [CrossRef] [PubMed]

61. Yuste, J.; Botto, M.; Paton, J.C.; Holden, D.W.; Brown, J.S. Additive inhibition of complement deposition by pneumolysin and PspA facilitates Streptococcus pneumoniae septicemia. J. Immunol. 2005, 175, 1813-1819. [CrossRef] [PubMed]

62. Rosenow, C.; Ryan, P.; Weiser, J.N.; Johnson, S.; Fontan, P.; Ortqvist, A.; Masure, H.R. Contribution of novel choline-binding proteins to adherence, colonization and immunogenicity of Streptococcus pneumoniae. Mol. Microbiol. 1997, 25, 819-829. [CrossRef] [PubMed]

63. Sitkiewicz, I.; Stockbauer, K.E.; Musser, J.M. Secreted bacterial phospholipase A2 enzymes: Better living through phospholipolysis. Trends Microbiol. 2007, 15, 63-69. [CrossRef] [PubMed]

64. Cremers, A.J.H.; Mobegi, F.M.; van der Gaast-de Jongh, C.; van Weert, M.; van Opzeeland, F.J.; Vehkala, M.; Knol, M.J.; Bootsma, H.J.; Välimäki, N.; Croucher, N.J.; et al. The contribution of genetic variation of Streptococcus pneumoniae to the clinical manifestation of invasive pneumococcal disease. Clin. Infect. Dis. 2018. [CrossRef] [PubMed] 
65. Oda, M.; Domon, H.; Kurosawa, M.; Isono, T.; Maekawa, T.; Yamaguchi, M.; Kawabata, S.; Terao, Y. Streptococcus pyogenes Phospholipase A2 induces the expression of adhesion molecules on human umbilical vein endothelial cells and aorta of mice. Front. Cell. Infect. Microbiol. 2017, 7, 300. [CrossRef] [PubMed]

66. Tuomanen, E.; Liu, H.; Hengstler, B.; Zak, O.; Tomasz, A. The induction of meningeal inflammation by components of the pneumococcal cell wall. J. Infect. Dis. 1985, 151, 859-868. [CrossRef] [PubMed]

67. Wren, J.T.; Blevins, L.K.; Pang, B.; Roy, A.B.; Oliver, M.B.; Reimche, J.L.; Wozniak, J.E.; Alexander-Miller, M.A.; Swords, W.E. Pneumococcal Neuraminidase A (NanA) promotes biofilm formation and synergizes with Influenza A virus in nasal colonization and middle ear infection. Infect. Immun. 2017, 85, e01044-16. [CrossRef] [PubMed]

68. Janoff, E.N.; Rubins, J.B.; Fasching, C.; Charboneau, D.; Rahkola, J.T.; Plaut, A.G.; Weiser, J.N. Pneumococcal IgA1 protease subverts specific protection by human IgA1. Mucosal Immunol. 2014, 7, 249-256. [CrossRef] [PubMed]

69. Suits, M.D.; Pluvinage, B.; Law, A.; Liu, Y.; Palma, A.S.; Chai, W.; Feizi, T.; Boraston, A.B. Conformational analysis of the Streptococcus pneumoniae hyaluronate lyase and characterization of its hyaluronan-specific carbohydrate-binding module. J. Biol. Chem. 2014, 289, 27264-27277. [CrossRef] [PubMed]

70. Berry, A.M.; Paton, J.C. Additive attenuation of virulence of Streptococcus pneumoniae by mutation of the genes encoding pneumolysin and other putative pneumococcal virulence proteins. Infect. Immun. 2000, 68, 133-140. [CrossRef] [PubMed]

71. Pericone, C.D.; Overweg, K.; Hermans, P.W.; Weiser, J.N. Inhibitory and bactericidal effects of hydrogen peroxide production by Streptococcus pneumoniae on other inhabitants of the upper respiratory tract. Infect. Immun. 2000, 68, 3990-3997. [CrossRef] [PubMed]

72. Paton, J.C.; Andrew, P.W.; Boulnois, G.J.; Mitchell, T.J. Molecular analysis of the pathogenicity of Streptococcus pneumoniae: The role of pneumococcal proteins. Annu. Rev. Microbiol. 1993, 47, 89-115. [CrossRef] [PubMed]

73. Price, K.E.; Greene, N.G.; Camilli, A. Export requirements of pneumolysin in Streptococcus pneumoniae. J. Bacteriol. 2012, 194, 3651-3660. [CrossRef] [PubMed]

74. van Pee, K.; Mulvihill, E.; Müller, D.J.; Yildiz, Ö. Unraveling the pore-forming steps of pneumolysin from Streptococcus pneumoniae. Nano Lett. 2016, 16, 7915-7924. [CrossRef] [PubMed]

75. Marriott, H.M.; Mitchell, T.J.; Dockrell, D.H. Pneumolysin: A double-edged sword during the host-pathogen interaction. Curr. Mol. Med. 2008, 8, 497-509. [CrossRef] [PubMed]

76. Nagai, K.; Domon, H.; Maekawa, T.; Oda, M.; Hiyoshi, T.; Tamura, H.; Yonezawa, D.; Arai, Y.; Yokoji, M.; Tabeta, K. Pneumococcal DNA-binding proteins released through autolysis induce the production of proinflammatory cytokines via toll-like receptor 4. Cell. Immunol. 2018, 325, 14-22. [CrossRef] [PubMed]

77. Witzenrath, M.; Pache, F.; Lorenz, D.; Koppe, U.; Gutbier, B.; Tabeling, C.; Reppe, K.; Meixenberger, K.; Dorhoi, A.; Ma, J.; et al. The NLRP3 inflammasome is differentially activated by pneumolysin variants and contributes to host defense in pneumococcal pneumonia. J. Immunol. 2011, 187, 434-440. [CrossRef] [PubMed]

78. Martner, A.; Dahlgren, C.; Paton, J.C.; Wold, A.E. Pneumolysin released during Streptococcus pneumoniae autolysis is a potent activator of intracellular oxygen radical production in neutrophils. Infect. Immun. 2008, 76, 4079-4087. [CrossRef] [PubMed]

79. Hirst, R.A.; Rutman, A.; Sikand, K.; Andrew, P.W.; Mitchell, T.J.; O'Callaghan, C. Effect of pneumolysin on rat brain ciliary function: Comparison of brain slices with cultured ependymal cells. Pediatr. Res. 2000, 47, 381-384. [CrossRef] [PubMed]

80. Hirst, R.A.; Gosai, B.; Rutman, A.; Andrew, P.W.; O'Callaghan, C. Streptococcus pneumoniae damages the ciliated ependyma of the brain during meningitis. Infect. Immun. 2003, 71, 6095-6100. [CrossRef] [PubMed]

81. Zysk, G.; Schneider-Wald, B.K.; Hwang, J.H.; Bejo, L.; Kim, K.S.; Mitchell, T.J.; Hakenbeck, R.; Heinz, H.P. Pneumolysin is the main inducer of cytotoxicity to brain microvascular endothelial cells caused by Streptococcus pneumoniae. Infect. Immun. 2001, 69, 845-852. [CrossRef] [PubMed]

82. Braun, J.S.; Hoffmann, O.; Schickhaus, M.; Freyer, D.; Dagand, E.; Bermpohl, D.; Mitchell, T.J.; Bechmann, I.; Weber, J.R. Pneumolysin causes neuronal cell death through mitochondrial damage. Infect. Immun. 2007, 75, 4245-4254. [CrossRef] [PubMed]

83. Kim, J.Y.; Paton, J.C.; Briles, D.E.; Rhee, D.K.; Pyo, S. Streptococcus pneumoniae induces pyroptosis through the regulation of autophagy in murine microglia. Oncotarget 2015, 6, 44161-44178. [CrossRef] [PubMed] 
84. Hupp, S.; Heimeroth, V.; Wippel, C.; Förtsch, C.; Ma, J.; Mitchell, T.J.; Iliev, A.I. Astrocytic tissue remodeling by the meningitis neurotoxin pneumolysin facilitates pathogen tissue penetration and produces interstitial brain edema. Glia 2012, 60, 137-146. [CrossRef] [PubMed]

85. Wall, E.C.; Gordon, S.B.; Hussain, S.; Goonetilleke, U.R.; Gritzfeld, J.; Scarborough, M.; Kadioglu, A. Persistence of pneumolysin in the cerebrospinal fluid of patients with pneumococcal meningitis is associated with mortality. Clin. Infect. Dis. 2012, 54, 701-705. [CrossRef] [PubMed]

86. Hirst, R.A.; Gosai, B.; Rutman, A.; Guerin, C.J.; Nicotera, P.; Andrew, P.W.; O'Callaghan, C. Streptococcus pneumoniae deficient in pneumolysin or autolysin has reduced virulence in meningitis. J. Infect. Dis. 2008, 197, 744-751. [CrossRef] [PubMed]

87. Yau, B. Pathogenesis of Pneumococcal Meningitis. Ph.D. Thesis, University of Sydney, Sydney, Australia, 2014; pp. 118-121.

88. Yamasaki, R.; Lu, H.; Butovsky, O.; Ohno, N.; Rietsch, A.M.; Cialic, R.; Wu, P.M.; Doykan, C.E.; Lin, J.; Cotleur, A.C.; et al. Differential roles of microglia and monocytes in the inflamed central nervous system. J. Exp. Med. 2014, 211, 1533-1549. [CrossRef] [PubMed]

89. Barichello, T.; Generoso, J.S.; Simões, L.R.; Goularte, J.A.; Petronilho, F.; Saigal, P.; Badawy, M.; Quevedo, J. Role of microglial activation in the pathophysiology of bacterial meningitis. Mol. Neurobiol. 2016, 53, 1770-1781. [CrossRef] [PubMed]

90. Ribes, S.; Ebert, S.; Regen, T.; Agarwal, A.; Tauber, S.C.; Czesnik, D.; Spreer, A.; Bunkowski, S.; Eiffert, H.; Hanisch, U.K.; et al. Toll-like receptor stimulation enhances phagocytosis and intracellular killing of nonencapsulated and encapsulated Streptococcus pneumoniae by murine microglia. Infect. Immun. 2010, 78, 865-871. [CrossRef] [PubMed]

91. Peppoloni, S.; Colombari, B.; Beninati, C.; Felici, F.; Teti, G.; Speziale, P.; Ricci, S.; Ardizzoni, A.; Manca, L.; Blasi, E. The Spr1875 protein confers resistance to the microglia-mediated killing of Streptococcus pneumoniae. Microb. Pathog. 2013, 59-60, 42-47. [CrossRef] [PubMed]

92. Shaked, I.; Porat, Z.; Gersner, R.; Kipnis, J.; Schwartz, M. Early activation of microglia as antigen-presenting cells correlates with $\mathrm{T}$ cell-mediated protection and repair of the injured central nervous system. J. Neuroimmunol. 2004, 146, 84-93. [CrossRef] [PubMed]

93. Brandenburg, L.O.; Varoga, D.; Nicolaeva, N.; Leib, S.L.; Wilms, H.; Podschun, R.; Wruck, C.J.; Schröder, J.M.; Pufe, T.; Lucius, R. Role of glial cells in the functional expression of LL-37/rat cathelin-related antimicrobial peptide in meningitis. J. Neuropathol. Exp. Neurol. 2008, 67, 1041-1054. [CrossRef] [PubMed]

94. Vijay, K. Toll-like receptors in immunity and inflammatory diseases: Past, present, and future. Int. Immunopharmacol. 2018, 59, 391-412. [CrossRef] [PubMed]

95. Koppe, U.; Högner, K.; Doehn, J.M.; Müller, H.C.; Witzenrath, M.; Gutbier, B.; Bauer, S.; Pribyl, T.; Hammerschmidt, S.; Lohmeyer, J.; et al. Streptococcus pneumoniae stimulates a STING- and IFN regulatory factor 3-dependent type I IFN production in macrophages, which regulates RANTES production in macrophages, cocultured alveolar epithelial cells, and mouse lungs. J. Immunol. 2012, 188, 811-817. [CrossRef] [PubMed]

96. Yoshimura, A.; Lien, E.; Ingalls, R.R.; Tuomanen, E.; Dziarski, R.; Golenbock, D. Cutting edge: Recognition of Gram-positive bacterial cell wall components by the innate immune system occurs via Toll-like receptor 2. J. Immunol. 1999, 163, 1-5. [PubMed]

97. Schroder, N.W.; Morath, S.; Alexander, C.; Hamann, L.; Hartung, T.; Zähringer, U.; Göbel, U.B.; Weber, J.R.; Schumann, R.R. Lipoteichoic acid (LTA) of Streptococcus pneumoniae and Staphylococcus aureus activates immune cells via Toll-like receptor (TLR)-2, lipopolysaccharide-binding protein (LBP), and CD14, whereas TLR-4 and MD-2 are not involved. J. Biol. Chem. 2003, 278, 15587-15594. [CrossRef] [PubMed]

98. Tomlinson, G.; Chimalapati, S.; Pollard, T.; Lapp, T.; Cohen, J.; Camberlein, E.; Stafford, S.; Periselneris, J.; Aldridge, C.; Vollmer, W.; et al. TLR-mediated inflammatory responses to Streptococcus pneumoniae are highly dependent on surface expression of bacterial lipoproteins. J. Immunol. 2014, 193, 3736-3745. [CrossRef] [PubMed]

99. Santos-Sierra, S.; Golenbock, D.T.; Henneke, P. Toll-like receptor-dependent discrimination of streptococci. J. Endotoxin Res. 2006, 12, 307-312. [CrossRef] [PubMed]

100. Mogensen, T.H.; Paludan, S.R.; Kilian, M.; Ostergaard, L. Live Streptococcus pneumoniae, Haemophilus influenzae, and Neisseria meningitidis activate the inflammatory response through Toll-like receptors 2, 4, and 9 in species-specific patterns. J. Leukocyte Biol. 2006, 80, 267-277. [CrossRef] [PubMed] 
101. Leifer, C.A.; Kennedy, M.N.; Mazzoni, A.; Lee, C.; Kruhlak, M.J.; Segal, D.M. TLR9 is localized in the endoplasmic reticulum prior to stimulation. J. Immunol. 2004, 173, 1179-1183. [CrossRef] [PubMed]

102. Walsh, J.G.; Muruve, D.A.; Power, C. Inflammasomes in the CNS. Nat. Rev. Neurosci. 2014, 15, 84-97. [CrossRef] [PubMed]

103. Rabes, A.; Suttorp, N.; Opitz, B. Inflammasomes in pneumococcal Infection: Innate immune sensing and bacterial evasion strategies. Curr. Top. Microbiol. Immunol. 2016, 397, 215-227. [PubMed]

104. McNeela, E.A.; Burke, A.; Neill, D.R.; Baxter, C.; Fernandes, V.E.; Ferreira, D.; Smeaton, S.; El-Rachkidy, R.; McLoughlin, R.M.; Mori, A.; et al. Pneumolysin activates the NLRP3 inflammasome and promotes proinflammatory cytokines independently of TLR4. PLoS Pathog. 2010, 6, e1001191. [CrossRef] [PubMed]

105. Schroder, K.; Zhou, R.; Tschopp, J. The NLRP3 inflammasome: A sensor for metabolic danger? Science 2010, 327, 296-300. [CrossRef] [PubMed]

106. Hoegen, T.; Tremel, N.; Klein, M.; Angele, B.; Wagner, H.; Kirschning, C.; Pfister, H.W.; Fontana, A.; Hammerschmidt, S.; Koedel, U. The NLRP3 inflammasome contributes to brain injury in pneumococcal meningitis and is activated through ATP-dependent lysosomal cathepsin B release. J. Immunol. 2011, 187, 5440-5451. [CrossRef] [PubMed]

107. Fang, R.; Hara, H.; Sakai, S.; Hernandez-Cuellar, E.; Mitsuyama, M.; Kawamura, I.; Tsuchiya, K. Type I interferon signaling regulates activation of the absent in melanoma 2 inflammasome during Streptococcus pneumoniae infection. Infect. Immun. 2014, 82, 2310-2317. [CrossRef] [PubMed]

108. Sollberger, G.; Strittmatter, G.E.; Garstkiewicz, M.; Sand, J.; Beer, H.D. Caspase-1: The inflammasome and beyond. Innate Immun. 2014, 20, 115-125. [CrossRef] [PubMed]

109. Geldhoff, M.; Mook-Kanamori, B.B.; Brouwer, M.C.; Troost, D.; Leemans, J.C.; Flavell, R.A.; Van der Ende, A.; Van der Poll, T.; Van de Beek, D. Inflammasome activation mediates inflammation and outcome in humans and mice with pneumococcal meningitis. BMC Infect. Dis. 2013, 13, 358. [CrossRef] [PubMed]

110. Mitchell, A.J.; Yau, B.; McQuillan, J.A.; Ball, H.J.; Too, L.K.; Abtin, A.; Hertzog, P.; Leib, S.L.; Jones, C.A.; Gerega, S.K.; et al. Inflammasome-dependent IFN-gamma drives pathogenesis in Streptococcus pneumoniae meningitis. J. Immunol. 2012, 189, 4970-4980. [CrossRef] [PubMed]

111. Ferwerda, B.; Valls Serón, M.; Jongejan, A.; Zwinderman, A.H.; Geldhoff, M.; van der Ende, A.; Baas, F.; Brouwer, M.C.; van de Beek, D. Variation of 46 Innate Immune genes evaluated for their contribution in pneumococcal meningitis susceptibility and outcome. eBioMedicine 2016, 10, 77-84. [CrossRef] [PubMed]

112. Wall, E.C.; Gritzfeld, J.F.; Scarborough, M.; Ajdukiewicz, K.M.; Mukaka, M.; Corless, C.; Lalloo, D.G.; Gordon, S.B. Genomic pneumococcal load and CSF cytokines are not related to outcome in Malawian adults with meningitis. J. Infect. 2014, 69, 440-446. [CrossRef] [PubMed]

113. Rusconi, F.; Parizzi, F.; Garlaschi, L.; Assael, B.M.; Sironi, M.; Ghezzi, P.; Mantovani, A. Interleukin 6 activity in infants and children with bacterial meningitis. The Collaborative Study on Meningitis. Pediatr. Infect. Dis. J. 1991, 10, 117-121. [CrossRef] [PubMed]

114. Coutinho, L.G.; Grandgirard, D.; Leib, S.L.; Agnez-Lima, L.F. Cerebrospinal-fluid cytokine and chemokine profile in patients with pneumococcal and meningococcal meningitis. BMC Infect. Dis. 2013, 13, 326. [CrossRef] [PubMed]

115. Diab, A.; Zhu, J.; Lindquist, L.; Wretlind, B.; Bakhiet, M.; Link, H. Haemophilus influenzae and Streptococcus pneumoniae induce different intracerebral mRNA cytokine patterns during the course of experimental bacterial meningitis. Clin. Exp. Immunol. 1997, 109, 233-241. [CrossRef] [PubMed]

116. Mook-Kanamori, B.; Geldhoff, M.; Troost, D.; van der Poll, T.; van de Beek, D. Characterization of a pneumococcal meningitis mouse model. BMC Infect. Dis. 2012, 12, 71. [CrossRef] [PubMed]

117. Xu, D.; Lian, D.; Wu, J.; Liu, Y.; Zhu, M.; Sun, J.; He, D.; Li, L. Brain-derived neurotrophic factor reduces inflammation and hippocampal apoptosis in experimental Streptococcus pneumoniae meningitis. J. Neuroinflamm. 2017, 14, 156. [CrossRef] [PubMed]

118. Yau, B.; Too, L.K.; Ball, H.J.; Hunt, N.H. TIGR4 strain causes more severe disease than WU2 strain in a mouse model of Streptococcus pneumoniae meningitis: A common pathogenic role for interferon-gamma. Microbes Infect. 2017, 19, 413-421. [CrossRef] [PubMed]

119. Polfliet, M.M.; Zwijnenburg, P.J.; van Furth, A.M.; van der Poll, T.; Döpp, E.A.; Renardel de Lavalette, C.; van Kesteren-Hendrikx, E.M.; van Rooijen, N.; Dijkstra, C.D.; van den Berg, T.K. Meningeal and perivascular macrophages of the central nervous system play a protective role during bacterial meningitis. J. Immunol. 2001, 167, 4644-4650. [CrossRef] [PubMed] 
120. Ramesh, G.; MacLean, A.G.; Philipp, M.T. Cytokines and chemokines at the crossroads of neuroinflammation, neurodegeneration, and neuropathic pain. Mediat. Inflamm. 2013, 2013, 480739. [CrossRef] [PubMed]

121. Takeshita, Y.; Ransohoff, R.M. Inflammatory cell trafficking across the blood-brain barrier: Chemokine regulation and in vitro models. Immunol. Rev. 2012, 248, 228-239. [CrossRef] [PubMed]

122. Man, S.; Tucky, B.; Cotleur, A.; Drazba, J.; Takeshita, Y.; Ransohoff, R.M. CXCL12-induced monocyte-endothelial interactions promote lymphocyte transmigration across an in vitro blood-brain barrier. Sci. Transl. Med. 2012, 4, 119ra14. [CrossRef] [PubMed]

123. Carman, C.V. Mechanisms for transcellular diapedesis: Probing and pathfinding by 'invadosome-like protrusions'. J. Cell Sci. 2009, 122, 3025-3035. [CrossRef] [PubMed]

124. Wewer, C.; Seibt, A.; Wolburg, H.; Greune, L.; Schmidt, M.A.; Berger, J.; Galla, H.J.; Quitsch, U.; Schwerk, C.; Schroten, H.; et al. Transcellular migration of neutrophil granulocytes through the blood-cerebrospinal fluid barrier after infection with Streptococcus suis. J. Neuroinflamm. 2011, 8, 51. [CrossRef] [PubMed]

125. Kornelisse, R.F.; Westerbeek, C.M.; Spoor, A.B.; van der Heijde, B.; Spanjaard, L.; Neijens, H.J.; de Groot, R. Pneumococcal meningitis in children: Prognostic indicators and outcome. Clin. Infect. Dis. 1995, 21, 1390-1397. [CrossRef] [PubMed]

126. Brandt, C.T. Experimental studies of pneumococcal meningitis. Dan. Med. Bull. 2010, 57, B4119. [PubMed]

127. Yau, B. Pathogenesis of Pneumococcal Meningitis. Ph.D. Thesis, University of Sydney, Sydney, Australia, 2014; pp. 174-175.

128. Koedel, U.; Frankenberg, T.; Kirschnek, S.; Obermaier, B.; Häcker, H.; Paul, R.; Häcker, G. Apoptosis is essential for neutrophil functional shutdown and determines tissue damage in experimental pneumococcal meningitis. PLoS Pathog. 2009, 5, e1000461. [CrossRef] [PubMed]

129. Too, L.K.; Mitchell, A.J.; McGregor, I.S.; Hunt, N.H. Antibody-induced neutrophil depletion prior to the onset of pneumococcal meningitis influences long-term neurological complications in mice. Brain Behav. Immun. 2016, 56, 68-83. [CrossRef] [PubMed]

130. Barichello, T.; Collodel, A.; Generoso, J.S.; Simões, L.R.; Moreira, A.P.; Ceretta, R.A.; Petronilho, F.; Quevedo, J. Targets for adjunctive therapy in pneumococcal meningitis. J. Neuroimmunol. 2015, 278, 262-270. [CrossRef] [PubMed]

131. Barichello, T.; dos Santos, I.; Savi, G.D.; Simões, L.R.; Silvestre, T.; Comim, C.M.; Sachs, D.; Teixeira, M.M.; Teixeira, A.L.; Quevedo, J. TNF-alpha, IL-1beta, IL-6, and cinc-1 levels in rat brain after meningitis induced by Streptococcus pneumoniae. J. Neuroimmunol. 2010, 221, 42-45. [CrossRef] [PubMed]

132. Yau, B.; Mitchell, A.J.; Too, L.K.; Ball, H.J.; Hunt, N.H. Interferon-gamma-induced nitric oxide synthase-2 contributes to blood/brain barrier dysfunction and acute mortality in experimental Streptococcus pneumoniae meningitis. J. Interferon Cytokine Res. 2016, 36, 86-99. [CrossRef] [PubMed]

133. Grandgirard, D.; Gäumann, R.; Coulibaly, B.; Dangy, J.P.; Sie, A.; Junghanss, T.; Schudel, H.; Pluschke, G.; Leib, S.L. The causative pathogen determines the inflammatory profile in cerebrospinal fluid and outcome in patients with bacterial meningitis. Mediat. Inflamm. 2013, 2013, 312476. [CrossRef] [PubMed]

134. Quagliarello, V.J.; Wispelwey, B.; Long, W.J., Jr.; Scheld, W.M. Recombinant human interleukin-1 induces meningitis and blood-brain barrier injury in the rat. Characterization and comparison with tumor necrosis factor. J. Clin. Investig. 1991, 87, 1360-1366. [CrossRef] [PubMed]

135. Wellmer, A.; Gerber, J.; Ragheb, J.; Zysk, G.; Kunst, T.; Smirnov, A.; Brück, W.; Nau, R. Effect of deficiency of tumor necrosis factor alpha or both of its receptors on Streptococcus pneumoniae central nervous system infection and peritonitis. Infect. Immun. 2001, 69, 6881-6886. [CrossRef] [PubMed]

136. Albrecht, L.J.; Tauber, S.C.; Merres, J.; Kress, E.; Stope, M.B.; Jansen, S.; Pufe, T.; Brandenburg, L.O. Lack of proinflammatory cytokine interleukin- 6 or tumor necrosis factor receptor- 1 results in a failure of the innate immune response after bacterial meningitis. Mediat. Inflamm. 2016, 2016, 7678542. [CrossRef] [PubMed]

137. Paul, R.; Koedel, U.; Winkler, F.; Kieseier, B.C.; Fontana, A.; Kopf, M.; Hartung, H.P.; Pfister, H.W. Lack of IL-6 augments inflammatory response but decreases vascular permeability in bacterial meningitis. Brain 2003, 126, 1873-1882. [CrossRef] [PubMed]

138. Koedel, U.; Winkler, F.; Angele, B.; Fontana, A.; Flavell, R.A.; Pfister, H.W. Role of Caspase-1 in experimental pneumococcal meningitis: Evidence from pharmacologic Caspase inhibition and Caspase-1-deficient mice. Ann. Neurol. 2002, 51, 319-329. [CrossRef] [PubMed] 
139. Zwijnenburg, P.J.; van der Poll, T.; Florquin, S.; Roord, J.J.; Van Furth, A.M. IL-1 receptor type 1 gene-deficient mice demonstrate an impaired host defense against pneumococcal meningitis. J. Immunol. 2003, 170, 4724-4730. [CrossRef] [PubMed]

140. Kornelisse, R.F.; Hack, C.E.; Savelkoul, H.F.; van der Pouw Kraan, T.C.; Hop, W.C.; van Mierlo, G.; Suur, M.H.; Neijens, H.J.; de Groot, R. Intrathecal production of interleukin-12 and gamma interferon in patients with bacterial meningitis. Infect. Immun. 1997, 65, 877-881. [PubMed]

141. Too, L.K.; Ball, H.J.; McGregor, I.S.; Hunt, N.H. The pro-inflammatory cytokine interferon-gamma is an important driver of neuropathology and behavioural sequelae in experimental pneumococcal meningitis. Brain Behav. Immun. 2014, 40, 252-268. [CrossRef] [PubMed]

142. Pettini, E.; Fiorino, F.; Cuppone, A.M.; Iannelli, F.; Medaglini, D.; Pozzi, G. Interferon-gamma from brain leukocytes enhances meningitis by type 4 Streptococcus pneumoniae. Front. Microbiol. 2015, 6, 1340. [CrossRef] [PubMed]

143. Hausler, K.G.; Prinz, M.; Nolte, C.; Weber, J.R.; Schumann, R.R.; Kettenmann, H.; Hanisch, U.K. Interferon-gamma differentially modulates the release of cytokines and chemokines in lipopolysaccharideand pneumococcal cell wall-stimulated mouse microglia and macrophages. Eur. J. Neurosci. 2002, 16, 2113-2122. [CrossRef] [PubMed]

144. Okamura, H.; Kashiwamura, S.; Tsutsui, H.; Yoshimoto, T.; Nakanishi, K. Regulation of interferon-gamma production by IL-12 and IL-18. Curr. Opin. Immunol. 1998, 10, 259-264. [CrossRef]

145. Barichello, T.; Generoso, J.S.; Simões, L.R.; Elias, S.G.; Quevedo, J. Role of oxidative stress in the pathophysiology of pneumococcal meningitis. Oxid. Med. Cell. Longev. 2013, 2013, 371465. [CrossRef] [PubMed]

146. Klein, M.; Koedel, U.; Pfister, H.W. Oxidative stress in pneumococcal meningitis: A future target for adjunctive therapy? Prog. Neurobiol. 2006, 80, 269-280. [CrossRef] [PubMed]

147. Schaper, M.; Leib, S.L.; Meli, D.N.; Brandes, R.P.; Täuber, M.G.; Christen, S. Differential effect of p47phox and gp91phox deficiency on the course of Pneumococcal Meningitis. Infect. Immun. 2003, 71, 4087-4092. [CrossRef] [PubMed]

148. Barichello, T.; Lemos, J.C.; Generoso, J.S.; Cipriano, A.L.; Milioli, G.L.; Marcelino, D.M.; Vuolo, F.; Petronilho, F.; Dal-Pizzol, F.; Vilela, M.C. Oxidative stress, cytokine/chemokine and disruption of blood-brain barrier in neonate rats after meningitis by Streptococcus agalactiae. Neurochem. Res. 2011, 36, 1922-1930. [CrossRef] [PubMed]

149. Rai, P.; Parrish, M.; Tay, I.J.; Li, N.; Ackerman, S.; He, F.; Kwang, J.; Chow, V.T. Engelward BP4. Streptococcus pneumoniae secretes hydrogen peroxide leading to DNA damage and apoptosis in lung cells. Proc. Natl. Acad. Sci. USA 2015, 112, E3421-E3430. [CrossRef] [PubMed]

150. Kastenbauer, S.; Koedel, U.; Pfister, H.W. Role of peroxynitrite as a mediator of pathophysiological alterations in experimental pneumococcal meningitis. J. Infect. Dis. 1999, 180, 1164-1170. [CrossRef] [PubMed]

151. Meli, D.N.; Christen, S.; Leib, S.L. Matrix metalloproteinase-9 in pneumococcal meningitis: Activation via an oxidative pathway. J. Infect. Dis. 2003, 187, 1411-1415. [CrossRef] [PubMed]

152. Pfister, H.W.; Koedel, U.; Dirnagl, U.; Haberl, R.L.; Feiden, W.; Einhäupl, K.M. Superoxide dismutase inhibits brain oedema formation in experimental pneumococcal meningitis. Acta Neurochir. Suppl. 1990, 51, 378-380. [PubMed]

153. Pfister, H.W.; Koedel, U.; Lorenzl, S.; Tomasz, A. Antioxidants attenuate microvascular changes in the early phase of experimental pneumococcal meningitis in rats. Stroke 1992, 23, 1798-1804. [CrossRef] [PubMed]

154. Kastenbauer, S.; Koedel, U.; Becker, B.F.; Pfister, H.W. Oxidative stress in bacterial meningitis in humans. Neurology 2002, 58, 186-191. [CrossRef] [PubMed]

155. Winkler, F.; Koedel, U.; Kastenbauer, S.; Pfister, H.W. Differential expression of nitric oxide synthases in bacterial meningitis: Role of the inducible isoform for blood-brain barrier breakdown. J. Infect. Dis. 2001, 183, 1749-1759. [CrossRef] [PubMed]

156. Braun, J.S.; Novak, R.; Herzog, K.H.; Bodner, S.M.; Cleveland, J.L.; Tuomanen, E.I. Neuroprotection by a caspase inhibitor in acute bacterial meningitis. Nat. Med. 1999, 5, 298-302. [CrossRef] [PubMed]

157. Koedel, U.; Paul, R.; Winkler, F.; Kastenbauer, S.; Huang, P.L.; Pfister, H.W. Lack of endothelial nitric oxide synthase aggravates murine pneumococcal meningitis. J. Neuropathol. Exp. Neurol. 2001, 60, 1041-1050. [CrossRef] [PubMed] 
158. Li, Z.; Ma, Q.Q.; Yan, Y.; Xu, F.D.; Zhang, X.Y.; Zhou, W.Q.; Feng, Z.C. Edaravone attenuates hippocampal damage in an infant mouse model of pneumococcal meningitis by reducing HMGB1 and iNOS expression via the Nrf2/HO-1 pathway. Acta Pharmacol. Sin. 2016, 37, 1298-1306. [CrossRef] [PubMed]

159. Konnecke, H.; Bechmann, I. The role of microglia and matrix metalloproteinases involvement in neuroinflammation and gliomas. Clin. Dev. Immunol. 2013, 2013, 914104. [CrossRef] [PubMed]

160. Leib, S.L.; Leppert, D.; Clements, J.; Täuber, M.G. Matrix metalloproteinases contribute to brain damage in experimental pneumococcal meningitis. Infect. Immun. 2000, 68, 615-620. [CrossRef] [PubMed]

161. Leppert, D.; Leib, S.L.; Grygar, C.; Miller, K.M.; Schaad, U.B.; Holländer, G.A. Matrix metalloproteinase (MMP)-8 and MMP-9 in cerebrospinal fluid during bacterial meningitis: Association with blood-brain barrier damage and neurological sequelae. Clin. Infect. Dis. 2000, 31, 80-84. [CrossRef] [PubMed]

162. Liechti, F.D.; Grandgirard, D.; Leppert, D.; Leib, S.L. Matrix metalloproteinase inhibition lowers mortality and brain injury in experimental pneumococcal meningitis. Infect. Immun. 2014, 82, 1710-1718. [CrossRef] [PubMed]

163. Leib, S.L.; Clements, J.M.; Lindberg, R.L.; Heimgartner, C.; Loeffler, J.M.; Pfister, L.A.; Täuber, M.G.; Leppert, D. Inhibition of matrix metalloproteinases and tumour necrosis factor alpha converting enzyme as adjuvant therapy in pneumococcal meningitis. Brain 2001, 124 Pt 9, 1734-1742. [CrossRef]

164. Liechti, F.D.; Bächtold, F.; Grandgirard, D.; Leppert, D.; Leib, S.L. The matrix metalloproteinase inhibitor RS-130830 attenuates brain injury in experimental pneumococcal meningitis. J. Neuroinflamm. 2015, 12, 43. [CrossRef] [PubMed]

165. Barichello, T.; Generoso, J.S.; Michelon, C.M.; Simões, L.R.; Elias, S.G.; Vuolo, F.; Comim, C.M.; Dal-Pizzol, F.; Quevedo, J. Inhibition of matrix metalloproteinases-2 and -9 prevents cognitive impairment induced by pneumococcal meningitis in Wistar rats. Exp. Biol. Med. 2014, 239, 225-231. [CrossRef] [PubMed]

166. Meli, D.N.; Christen, S.; Leib, S.L.; Täuber, M.G. Current concepts in the pathogenesis of meningitis caused by Streptococcus pneumoniae. Curr. Opin. Infect. Dis. 2002, 15, 253-257. [CrossRef] [PubMed]

167. Klein, R.S.; Garber, C.; Howard, N. Infectious immunity in the central nervous system and brain function. Nat. Immunol. 2017, 18, 132-141. [CrossRef] [PubMed]

168. Klein, M.; Koedel, U.; Kastenbauer, S.; Pfister, H.W. Nitrogen and oxygen molecules in meningitis-associated labyrinthitis and hearing impairment. Infection 2008, 36, 2-14. [CrossRef] [PubMed]

169. Hogen, T.; Demel, C.; Giese, A.; Angele, B.; Pfister, H.W.; Koedel, U.; Klein, M. Adjunctive N-acetyl-L-cysteine in treatment of murine pneumococcal meningitis. Antimicrob. Agents Chemother. 2013, 57, 4825-4830. [CrossRef] [PubMed]

170. Hofer, S.; Grandgirard, D.; Burri, D.; Fröhlich, T.K.; Leib, S.L. Bacterial meningitis impairs hippocampal neurogenesis. J. Neuropathol. Exp. Neurol. 2011, 70, 890-899. [CrossRef] [PubMed]

171. Clark, I.A.; Vissel, B. The meteorology of cytokine storms, and the clinical usefulness of this knowledge. Semin. Immunopathol. 2017, 39, 505-516. [CrossRef] [PubMed]

172. Fuster-Matanzo, A.; Llorens-Martín, M.; Hernández, F.; Avila, J. Role of neuroinflammation in adult neurogenesis and Alzheimer disease: Therapeutic approaches. Mediat. Inflamm. 2013, 2013, 260925. [CrossRef] [PubMed]

173. Schmidt, E.D.; Schoffelmeer, A.N.; De Vries, T.J.; Wardeh, G.; Dogterom, G.; Bol, J.G.; Binnekade, R.; Tilders, F.J.; et al. A single administration of interleukin-1 or amphetamine induces long-lasting increases in evoked noradrenaline release in the hypothalamus and sensitization of ACTH and corticosterone responses in rats. Eur. J. Neurosci. 2001, 13, 1923-1930. [CrossRef] [PubMed]

174. Hennessy, M.B.; Paik, K.D.; Caraway, J.D.; Schiml, P.A.; Deak, T. Proinflammatory activity and the sensitization of depressive-like behavior during maternal separation. Behav. Neurosci. 2011, 125, 426-433. [CrossRef] [PubMed]

175. Kennedy, R.H.; Silver, R. Neuroimmune Signaling: Cytokines and the Central Nervous System. In Neuroscience in the 21st Century: From Basic to Clinical; Pfaff, D.W., Volkow, N.D., Eds.; Springer: New York, NY, USA, 2016; pp. 601-641.

176. Barichello, T.; Generoso, J.S.; Simões, L.R.; Sharin, V.G.; Ceretta, R.A.; Dominguini, D.; Comim, C.M.; Vilela, M.C.; Teixeira, A.L.; Quevedo, J. Interleukin-1beta Receptor Antagonism Prevents Cognitive Impairment Following Experimental Bacterial Meningitis. Curr. Neurovasc. Res. 2015, 12, 253-261. [CrossRef] [PubMed] 
177. Roth, T.L. Epigenetic mechanisms in the development of behavior: Advances, challenges, and future promises of a new field. Dev. Psychopathol. 2013, 25, 1279-1291. [CrossRef] [PubMed]

178. Too, L.K. Acute Brain Pathology and Long-Term Neurological Sequelae in Experimental Pneumococcal Meningitis. PhD Thesis, University of Sydney, Sydney, Australia, 2014; pp. 232-237.

179. Obermeier, B.; Daneman, R.; Ransohoff, R.M. Development, maintenance and disruption of the blood-brain barrier. Nat. Med. 2013, 19, 1584-1596. [CrossRef] [PubMed]

180. Brouwer, M.C.; McIntyre, P.; Prasad, K.; van de Beek, D. Corticosteroids for acute bacterial meningitis. Cochrane Database Syst. Rev. 2015, Cd004405. [CrossRef] [PubMed]

181. Liu, X.; Han, Q.; Sun, R.; Li, Z. Dexamethasone regulation of matrix metalloproteinase expression in experimental pneumococcal meningitis. Brain Res. 2008, 1207, 237-243. [CrossRef] [PubMed]

(C) 2018 by the authors. Licensee MDPI, Basel, Switzerland. This article is an open access article distributed under the terms and conditions of the Creative Commons Attribution (CC BY) license (http:/ / creativecommons.org/licenses/by/4.0/). 